\title{
Fracture-induced softening for large-scale ice dynamics
}

\author{
T. Albrecht ${ }^{1,2}$ and A. Levermann ${ }^{1,2}$ \\ ${ }^{1}$ Earth System Analysis, Potsdam Institute for Climate Impact Research, Potsdam, Germany \\ ${ }^{2}$ Institute of Physics and Astronomy, University of Potsdam, Potsdam, Germany \\ Correspondence to: T. Albrecht (torsten.albrecht@pik-potsdam.de)
}

Received: 20 August 2013 - Published in The Cryosphere Discuss.: 9 September 2013

Revised: 31 January 2014 - Accepted: 26 February 2014 - Published: 8 April 2014

\begin{abstract}
Floating ice shelves can exert a retentive and hence stabilizing force onto the inland ice sheet of Antarctica. However, this effect has been observed to diminish by the dynamic effects of fracture processes within the protective ice shelves, leading to accelerated ice flow and hence to a sealevel contribution. In order to account for the macroscopic effect of fracture processes on large-scale viscous ice dynamics (i.e., ice-shelf scale) we apply a continuum representation of fractures and related fracture growth into the prognostic Parallel Ice Sheet Model (PISM) and compare the results to observations. To this end we introduce a higher order accuracy advection scheme for the transport of the two-dimensional fracture density across the regular computational grid. Dynamic coupling of fractures and ice flow is attained by a reduction of effective ice viscosity proportional to the inferred fracture density. This formulation implies the possibility of non-linear threshold behavior due to self-amplified fracturing in shear regions triggered by small variations in the fracture-initiation threshold. As a result of prognostic flow simulations, sharp across-flow velocity gradients appear in fracture-weakened regions. These modeled gradients compare well in magnitude and location with those in observed flow patterns. This model framework is in principle expandable to grounded ice streams and provides simple means of investigating climate-induced effects on fracturing (e.g., hydro fracturing) and hence on the ice flow. It further constitutes a physically sound basis for an enhanced fracture-based calving parameterization.
\end{abstract}

\section{Introduction}

The contemporarily observed sea-level change (Cazenave and Llovel, 2010; Church et al., 2011; Gregory et al., 2012) as well as the expected long-term sea-level commitment (Levermann et al., 2013) underpin the role of the contributions of the large polar ice sheets of Greenland and Antarctica (Van den Broeke et al., 2011; Rignot et al., 2011b; Shepherd et al., 2012; Hanna et al., 2013). Reliable and accurate process-based models are required to understand the involved complex processes and to provide confident projections of future sea-level rise (Bamber and Aspinall, 2013). Certain aspects of ice flow need a better representation in these models to account for the potential destabilization of key regions, such as the West Antarctic ice sheet (Bamber et al., 2009; Joughin and Alley, 2011). The retentive force of floating ice shelves that retains the oceanward ice flow (Dupont and Alley, 2005; Winkelmann et al., 2012; Gudmundsson, 2013) is of high relevance in this assessment. Most models neglect the feedback of fractures, which can repeal this buttressing effect of ice shelves (Borstad et al., 2013).

Fracture processes play a fundamental role in the dynamics of ice streams and ice shelves, in addition to ocean melt (Pritchard et al. 2012; Rignot et al., 2013), but also in interaction with external drivers, such as surface melt induced by atmospheric warming (MacAyeal and Sergienko, 2013). Fractures are mostly found as elongated structures of fragments or sequences of troughs and open crevasses, visible at the ice surface. These fracture bands are aligned along the ice flow with origin in the wake of topographic features such as ice rises, ice rumples or along ice stream inlets and usually extend the whole distance towards the calving front. On that journey along the stream, prevailing stresses can change 
and activate additional crevasse formation. While approaching the calving front, deep-reaching rifts were observed to initiate from crevasses and propagate horizontally up to 100km-long across flow units (Hulbe et al., 2010; Walker et al., 2013).

Fractures and ice flow interact in various ways. Considering the effect of the ice flow on fracture formation first, we can state, that certain dynamic regimes promote the formation of fractures. More precisely, they form in regions of strong shear or tensile flow for certain temperature and ice conditions (Schulson and Duval, 2009). External forces such as seasonal meltwater drainage can enhance the vertical propagation of existing surface fractures (Weertman, 1973; Van der Veen, 1998a), but snow drift, refreezing or recrystallization can cover and heal them. Similar effects underneath the ice shelf influence the formation and propagation of basal crevasses, which can reach far upward, producing a trough at the surface by viscous adjustment (Van der Veen, 1998b; McGrath et al., 2012b; Luckman et al., 2012; Vaughan et al., 2012). Generally, the ice-overburden pressure tends to close open crevasses as opposed to the tensile load (Nye, 1957) and to water pressure within the crevasse.

Considering the macroscopic feedback of fractures on the viscous ice flow, we can state that the abundance of fractures potentially affect the flow regime since horizontal (membrane) stresses cannot be effectively transferred across highly fractured regions due to the loss of mechanical integrity and the reduction of its load-bearing capacity (Borstad et al., 2012, 2013). Inverse modeling provides a snapshot quantification of the dynamic activity of mechanically weakened areas associated with fractures. Between those partly detached flow units, strong velocity gradients and consequently intense shear is observed, which cannot be reproduced in standard ice-flow models (discussed in Sandhäger et al., 2005; Humbert et al., 2009). In addition to the effect of fractures on the flow, the accretion of marine ice underneath similar ice shelf regions may play a relevant role explaining shear strain concentrations (Jansen et al., 2013).

Observations of fracture features at the surface provide an incomplete picture. That is, dynamically active zones such as highly fragmented shear zones are not necessarily visible for currently available resolutions and, vise versa, certain observable surface features may be irrelevant for the dynamics. Furthermore, the active areas often act as precursor for visible crevasse and rift formations (Bassis et al., 2008; Hulbe et al., 2010), which can be identified as mostly transversal structures often reaching far into undamaged areas. Huge rift systems can be completely deactivated (i.e., healed) when filled with mélange (Borstad et al., 2013). These complex implications questions the robustness of validating the computed dynamic effect of fractures against observed surface features associated with fractures. Inverse control methods provide an intelligent validation tool by inferring such active zones for a given snapshot of observed surface velocities (Khazendar et al., 2007; Borstad et al., 2012, 2013; Haber- mann et al., 2012, available as rheology inversion in PISM). Yet, controlling factors like ice fabric, marine ice or meltwater are implicitly included in the inferred result. If running the forward model, PISM does not distinguish between meteoric and marine ice, assuming constant density in the whole ice column.

Prognostic modeling is needed to understand the causalities and to reveal evolving characteristics of the interaction of flow and fracture dynamics, for example, investigating self-amplifying feedback mechanisms that are susceptible to changes in external conditions (Scambos et al., 2000, 2003; MacAyeal et al., 2003). Melting and hydro-fracturing causes enhanced structural weakening of the mechanical integrity in fractured regions (Scambos et al., 2009; Glasser and Scambos, 2008; Vieli et al., 2007; Khazendar et al., 2007; Van der Veen, 2007; McGrath et al., 2012a). This reduces the lateral support of the confinement and consequently the buttressing. Stronger shear and thinning in turn supports fracturing, which ultimately can destabilize the entire ice shelf, as observed in several cases along the Antarctic Peninsula (Cook and Vaughan, 2010). The disintegration of large parts of the ice shelves provokes a more efficient drainage of the upstream glaciers (Rignot et al., 2004; Rott et al., 2011).

Fracturing of ice represents a key process in the description of the complex ice-flow pattern and plays an important role in ice-shelf calving (Benn et al., 2007) and abrupt disintegration. Particle-flow models may provide a novel and promising representation of fracture formation and related iceberg calving (Bassis and Jacobs, 2013). For the initiation of fractures, different theories have been discussed and applied in several studies, considering ductile or brittle properties of the ice on different scales (Schulson and Duval, 2009). According to the strength-of-material theory, fractures form if the stress exceeds a material-specific threshold. As an alternative, fracture mechanics assume small cracks (of the order of centimeters), from which fractures initiate, due to stress concentrations at the crack tips. From there they propagate either horizontally (Hulbe et al., 2010) or vertically on rather short timescales (Van der Veen, 1998a, b). An accurate estimate of the maximal fracture depth requires accurate data of the vertical profiles of ice density and other physical parameters (Rist et al., 2002; Plate et al., 2012), and will not be further discussed in this study, though it might be part of future studies.

In this study we present a simplified framework of continuum damage evolution based on ideas by Pralong and Funk (2005) and Borstad et al. (2012), which we named "fracture density", adapted to the finite-difference Parallel Ice Sheet Model (Bueler and Brown, 2009; Winkelmann et al., 2011, based on PISM v.05; see documentation: www.pism-docs. org). In the first part we briefly resume the assumptions and methods of identifying regions of fracture initiation and corresponding fracture-density accumulation, which has been described in detail in Albrecht and Levermann (2012). A simple coupling relationship between fracture density and 
viscous-ice deformation is then presented and justified, following the analytical formulation by Borstad et al. (2012). Inherent non-linear effects such as multi-stability are investigated in a simplified model setup. Applying the proposed fracture coupling in simulations of several Antarctic ice shelves and comparing the results to observations provides a tool for calibrating employed parameters and thresholds and identifying qualitative differences in the flow field. A concluding discussion summarizes the findings and reveals limitations of the approach and also future applications, such as a fracture-induced calving parameterization (Duddu et al., 2013).

\section{The fracture-density concept}

The basic idea of the continuous, dynamically evolving fracture-density field, applied to ice shelves, has been introduced by Albrecht and Levermann (2012). The scalar value of the isotropic damage variable, $0 \leq \phi \leq 1$, called "fracture density", has been interpreted as a measure for the density of macroscopic fracture features per ice-shelf surface area. In this study we consider $\phi$ to be a relative volume measure of included voids as in the scalar damage interpretation. As a field variable, $\phi$ can be transported with the ice flow $v$ as

$\frac{\partial \phi}{\partial t}+\boldsymbol{v} \cdot \nabla \phi=f_{\mathrm{s}}+f_{\mathrm{h}}$.

In this simple advection equation $f_{\mathrm{s}}$ and $f_{\mathrm{h}}$ indicate the source and sink terms.

In areas, where a certain fracture-initiation threshold $\sigma_{\mathrm{cr}}$ is met, $\phi$ is assumed to grow with a rate that is proportional to the local maximum spreading rate, $\dot{\epsilon}_{+}$. This functional relationship accounts for the formation of new fractures within a grid cell and hence for fracture accumulation. Since brittle fractures, for example, surface and bottom crevasses, are likely produced in previously cracked regimes, we consider here the aggregated effect, not distinguishing between individual fracture representations. Rift propagation across flow domains is yet too complex to be modeled explicitly here. The presence of densely spaced fractures, however, restricts the rate of additional fracture formation by reducing the overall stress in their proximity, which is expressed simply by a reducing factor, $1-\phi$, in the fracture-density evolution function

$f_{\mathrm{s}}=\left\{\begin{array}{ll}\gamma \cdot \dot{\epsilon}_{+} \cdot(1-\phi), & \sigma_{\mathrm{t}} \geq \sigma_{\mathrm{cr}} \\ 0, & \sigma_{\mathrm{t}}<\sigma_{\mathrm{cr}}\end{array}\right.$.

Contributions to fracture density are expected in regions where the "effective-stress" ellipse, defined in terms of surface-parallel principal stresses, $\sigma_{+}$and $\sigma_{-}$, as

$\sigma_{\mathrm{t}}=\sqrt{\sigma_{+}^{2}+\sigma_{-}^{2}-\sigma_{+} \sigma_{-}}$,

exceeds the von-Mises critical strength $\sigma_{\mathrm{cr}}$ (von Mises, 1913; Vaughan, 1993). The fracture-density variable is then carried downstream with the ice velocity (here following the Shallow Shelf Approximation in Eq. 1).

Existing fractures can experience deactivation by snow cover and refreezing of mélange at the surface, or closure in moderate stress environments by the ice overburden pressure in both surface and bottom crevasses. This is expressed in a healing rate:

$f_{\mathrm{h}}=\left\{\begin{array}{ll}\gamma_{\mathrm{h}} \cdot\left(\dot{\epsilon}_{+}-\dot{\epsilon}_{\mathrm{h}}\right), & \dot{\epsilon}_{+} \leq \dot{\epsilon}_{\mathrm{h}} \\ 0, & \dot{\epsilon}_{+}>\dot{\epsilon}_{\mathrm{h}}\end{array}\right.$.

Depending on the local tensile strain-rate condition, $\dot{\epsilon}_{+} \leq \dot{\epsilon}_{\mathrm{h}}$, the advected fracture density is then reduced with the constant rate factor, $\gamma_{\mathrm{h}}$. Sensitivity of the fracture field to these parameters and their role for the steady-state fracture density have been evaluated in Albrecht and Levermann (2012). However, the insights of this previous study are associated with a model setup, where the evolving fracture-density pattern is considered for a prescribed ice thickness. In the following we take into account the macroscopic dynamic effect of the evolving fracture density on the ice viscosity to allow for a feedback onto the flow field and the ice geometry.

\section{Fracture-induced softening}

In this section we build on recent efforts and investigate the feedback mechanism of fracture formation and its cumulative imprint on the flow dynamics within a framework that is based on a simplified version of continuum damage mechanics (Pralong and Funk, 2005; Duddu and Waisman, 2012a, b). The fracture-density concept considers the firstorder effects and adopts a simpler foundation in order to reduce the parameter space of the more generally defined (power-law) continuum damage model. Fractures can be associated with voids in the ice body, that reduces the integrity of the ice body and stresses cannot be transferred properly any more, hence the ice loses its "load-bearing capacity" (Borstad et al., 2012). We hence consider the influence of fractures in the ice column on horizontal ice deformation. As observed in satellite images, bands of high fracture density, aligned along the flow, separate slow-moving areas from flow units coming in from different inlets with different speeds. From a macroscopic point of view, this mechanical decoupling along the suture zone corresponds to a softening effect of the ice that can be expressed in the model as a modified flow-enhancement factor $E_{\mathrm{A}}$ (Humbert, 2006; Humbert et al., 2009). Assuming the strain-equivalence between physical and effective spaces (Pralong and Funk, 2005; Duddu and Waisman, 2012a; Borstad et al., 2013), the stress-balance equation changes using a modified effective viscosity defined 

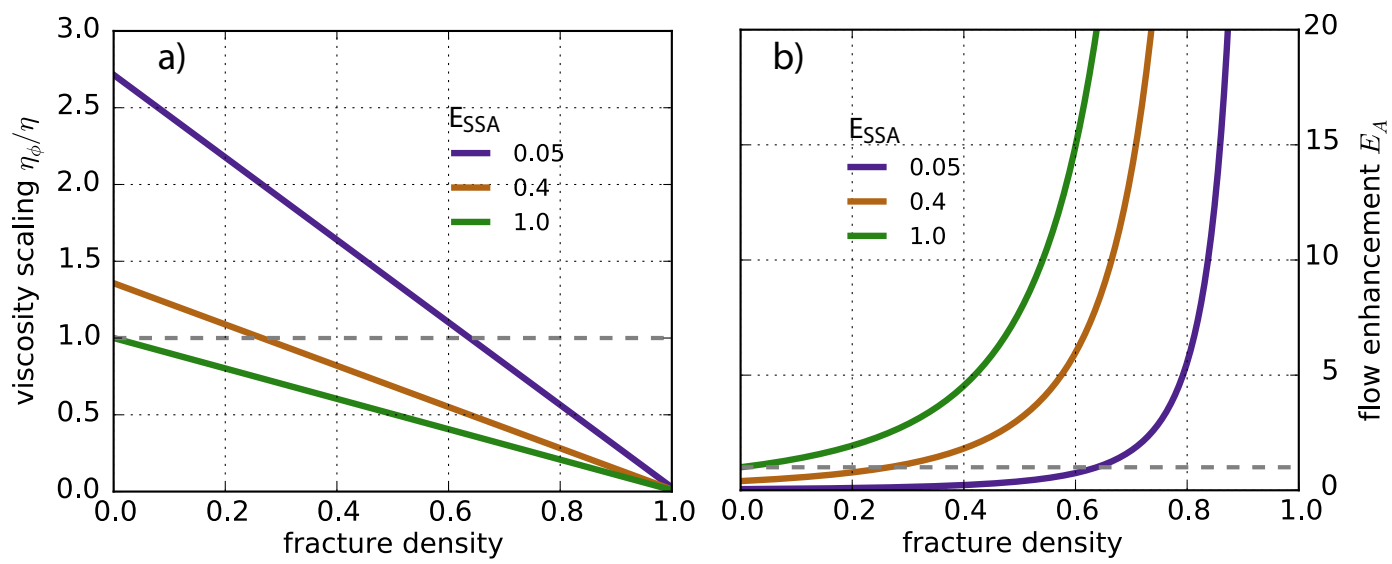

Fig. 1. Functional relationship of viscosity (a) and ice softening (b) with respect to fracture density as in Eq. (6) is shown for three SSAenhancement factors $E_{\mathrm{SSA}}$ (see legend). Base line for $E_{\mathrm{SSA}}=1$ is grey dashed.

as

$$
\begin{aligned}
\eta_{\phi} & =E_{\mathrm{A}}^{\frac{-1}{n}} \cdot \frac{1}{2} \cdot \dot{\epsilon}_{\mathrm{e}}^{\frac{1-n}{n}} \cdot \int B(T) \mathrm{d} z \\
& =E_{\phi}{ }^{\frac{-1}{n}} \cdot\left[E_{\mathrm{SSA}}^{\frac{-1}{n}} \cdot \frac{1}{2} \cdot \dot{\epsilon}_{\mathrm{e}}^{\frac{1-n}{n}} \cdot \int B(T) \mathrm{d} z\right]
\end{aligned}
$$

Here, $B(T)$ denotes ice hardness (or rigidity), which depends on the vertical temperature distribution, $T=T(z)$. PISM calculates temperature evolution using a semi-implicit scheme for the vertical diffusion and horizontal advection with the ice flow, where strain heating comes in as heat source. The effective strain rate, $\dot{\epsilon}_{\mathrm{e}}$, is the second invariant of the strainrate tensor (equivalent to the effective stress in Eq. 3), with $n=3$ the Glen's flow law parameter. The term in parentheses on the right hand side represents the standard viscosity used in PISM, where the enhancement factor for the Shallow Shelf Approximation, $E_{\mathrm{SSA}}$, is commonly used in ice shelf modeling, comprising anisotropy and other softening or stiffening effects of the intact ice (Ma et al., 2010; Winkelmann et al., 2011). However, $E_{\mathrm{SSA}}$ is taken to be constant in space and time. In contrast, $E_{\phi}{ }^{\frac{-1}{n}}$ represents an additional factor in Eq. (5) corresponding to the spatially varying fractureinduced softening.

We assume a simple functional relationship for this softening due to fractures, adopted in its analytical form from Borstad et al. (2012), written as

$E_{\phi}=[1-(1-\varepsilon) \cdot \phi]^{-n} \stackrel{\varepsilon=0}{\longrightarrow}[1-\phi]^{-n}$

For its implementation in the numerical model we introduce the parameter $\varepsilon$ as a lower limit for the softening, avoiding a degeneration of the equations. In the simulations presented here epsilon is $\varepsilon=0.001$.

The combined influence of the two unitless enhancement factors, $E_{\mathrm{A}}=E_{\mathrm{SSA}} \cdot E_{\phi}$, on the emerging non-linear coupling is shown in Fig. 1. For a fracture density of $\phi=0.5$, and hence half the undamaged viscosity, ice is stiffened by a factor $E_{\mathrm{A}}=0.4$ for very low SSA-enhancement, $E_{\mathrm{SSA}}=0.05$ (right panel). In contrast, the flow is softened by a factor $E_{\mathrm{A}}=8$ if no SSA-enhancement is applied $\left(E_{\mathrm{SSA}}=1\right)$. Regarding anisotropy for tensional ice-shelf flow, values of about $E_{\mathrm{SSA}}=0.6-0.7$ seem realistic (Ma et al., 2010). The low value of $E_{\mathrm{SSA}}=0.05$, as used in two applications to produce realistic velocities, also comprises other effects in the model setup (e.g., an overestimation of strain heating along the shearing margins). Due to the strong non-linearity, the total flow enhancement is almost an order of magnitude larger $\left(3 \leq E_{\mathrm{A}} \leq 59\right)$ for a fracture density of $\phi=0.75$ and a quarter of the undistorted ice viscosity. Approaching vanishing viscosity and hence infinite enhancement can be interpreted as pathway towards quasi-discontinuous model behavior, where domains seem mechanically decoupled. In this regime of fracture densities close to 1 , the comparably small residual value $\varepsilon$ limits ice softness to guarantee convergence of the stress balance calculation. Its sensitivity will not be discussed here.

The proposed model framework implies a potentially selfamplifying feedback mechanism: if fractures form in a certain region, the ice will be softened according to Eq. (6), which allows for stress concentration. This applies also in regions downstream of the formation area where the fractures are transported to. Stronger shear or tension increases the effective stress and if the critical threshold is met, additional fractures can form leading to an increasing fracture density where fractures otherwise would not from. Healing and numerical diffusion counteract the accumulation of fracture density, which otherwise would tend to approach asymptotically the upper bounding value 1 . 

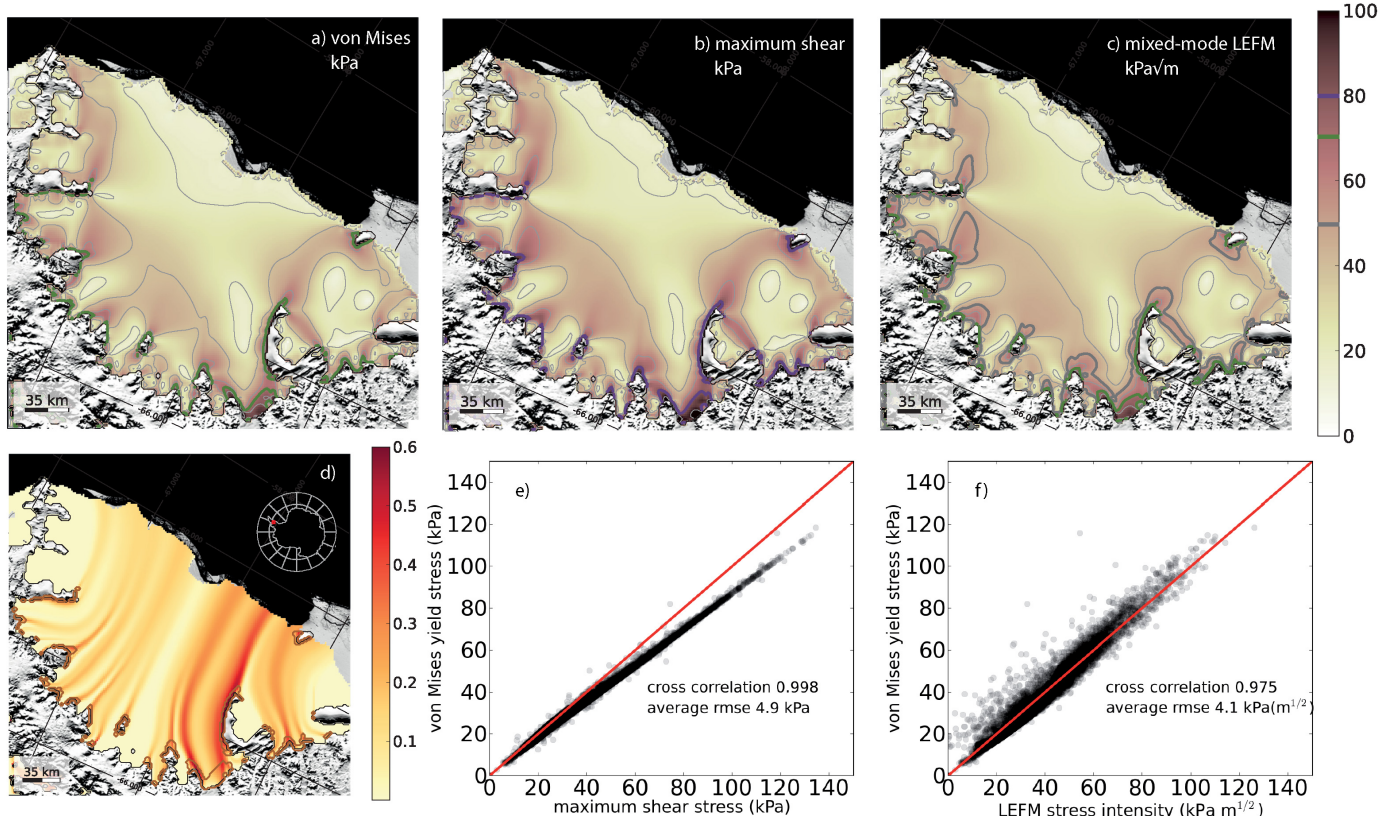

Fig. 2. Comparison of von-Mises effective stress (a), maximum-shear stress (b) and LEFM-stress intensity (c) in the Larsen C ice shelf region with thin grey contours every $20 \mathrm{kPa}(\sqrt{\mathrm{m}})$, green contour at $70 \mathrm{kPa}(\sqrt{\mathrm{m}})$ and violet at $80 \mathrm{kPa}$. Resultant steady-state fracture density is shown in the lower left panel, no healing or softening applied. Scatter plots in the lower right panels show the point-wise comparison for the given examples.

\section{Methods}

\subsection{Evaluating fracture initiation criteria}

Failure of ice occurs at stresses beyond certain thresholds and is hence typically expressed in terms of the strength of the ice. There is a variety of phenomenological standard failure criteria for the identification of regions where fracturing potentially is initiated. As one example of the strength of the material theory, we use the von-Mises criterion based on the maximum effective stress exceeding a critical value, $\sigma_{\mathrm{t}}>\sigma_{\mathrm{cr}}$ (Eq. 3), which is equivalent to the exceedance of a maximal distortion energy (von Mises, 1913; Vaughan, 1993).

In addition to the von-Mises criterion, we consider here for comparison the similar maximum shear stress criterion (a.k.a. Tresca or Guest criterion in literature)

$\sigma_{\mathrm{ms}}=\max \left(\left|\sigma_{+}\right|,\left|\sigma_{-}\right|,\left|\sigma_{+}-\sigma_{-}\right|\right)$.

In a computational setup of the Larsen $\mathrm{C}$ ice shelf with a resolution of $1.75 \mathrm{~km}$, this maximum shear stress is about $15 \%$ larger than the effective stress used in the von-Mises criterion (Fig. 2b, e). If the corresponding threshold is reduced by $15 \%$ with respect to the von-Mises strength $\left(\sigma_{\mathrm{t}} \geq 70 \mathrm{kPa}\right.$ and $\sigma_{\mathrm{ms}} \geq 80 \mathrm{kPa}$ coincide with $95 \%$ ) fracture formation is initiated in the same regions and very similar steady-state patterns of fracture density evolve.

As an alternative, a third criterion derived from Linear Elastic Fracture Mechanics (LEFM) is considered, that takes into account both shear and tensile modes of cracking in a biaxial stress field. It is based on the observation, that fractures propagate from stress concentrations at sharp pre-existing flaws in the ice, while the far-field load can be less than the strength of the ice. Following this approach, a single crevasse forms when the critical plane-strain fracture toughness $K_{\text {Ic }}$ is exceeded by the combined stress intensities, defined as

$\sqrt{\pi c}\left[\sigma_{n} \cos ^{3}\left(\frac{\theta}{2}\right)+\tau_{s} \cos \left(\frac{\theta}{2}\right) \sin (\theta)\right] \geq K_{\mathrm{Ic}}$

with $\theta=-2 \arctan \left(\frac{\sqrt{\sigma_{n}^{2}+8 \tau_{s}^{2}}-\sigma_{n}}{4 \tau_{s}}\right)$.

The parameter $c$ denotes the half-length of assumed preexisting edge cracks, $\sigma_{n}$ is the stress across to the crack opening and $\tau_{s}$ the shear stress along the crack planes (see (Erdogan and Sih, 1963; Shyam Sunder and Wu, 1990; Rist et al., 1999) and (Hulbe et al., 2010) for details). The fracture toughness for a given geometry of pre-existing flaws is density-dependent. For the low-density firn at the surface, a fracture toughness of $K_{\text {Ic }} \approx 50 \mathrm{kPa} \sqrt{\mathrm{m}}$ was obtained in laboratory experiments with ice core specimen from the Ronne Ice Shelf (Rist et al., 1999, 2002). Larger values of $K_{\mathrm{Ic}} \approx 150 \mathrm{kPa} \sqrt{\mathrm{m}}$ or more are expected for the meteoric or marine ice at the ice shelf bottom. For fracture fields of narrow-spaced crevasses, the fracture toughness for ice with included voids can even be twice or triple as high as for intact ice without voids (Van der Veen, 1998a). It appears that 
the initial crack half-length $c$ is a weakly confined parameter. Without making physically-based decisions about formulating the LEFM criterion, we assigned a value of $c=0.2 \mathrm{~m}$, such that the root mean square error in comparison to the von-Mises criterion becomes minimal within the computational setup of the Larsen $\mathrm{C}$ region (Fig. 2f). Jansen et al. (2010) indicate a unique pattern of potential crevasse opening for a given ratio of fracture toughness and half-length, which compares very well with Fig. 2c, (compare grey contour lines of $50 \mathrm{kPa} \sqrt{\mathrm{m}}$ ). Since the relevant formation areas of brittle fractures coincide mostly with those identified with the ductile von-Mises criterion (for $K_{\mathrm{Ic}}=70 \mathrm{kPa} \sqrt{\mathrm{m}}$ and $\sigma_{\mathrm{t}} \geq 70 \mathrm{kPa}$ fracture-formation area have a $75 \%$ match), the fracture-density pattern does not show major differences at the resolutions applied here. LEFM may provide a different pattern for better resolved geometries and physical choices of the parameter $c$. In the following study we use the von-Mises criterion only to identify regions of fracture initiation.

\subsection{Feature-preserving two-dimensional numerical advection scheme}

Standard upstream differencing schemes of first-order accuracy are a commonly applied and pragmatic choice to approximate hyperbolic-type partial differential equations as the advection equation in Eq. (1) (e.g., Press et al., 2009). However, these schemes are known to be numerically dissipative, that is, they tend to smear out well-defined structures, such as shocks (discontinuities) along the flow. In contrast, we consider confined stripes of fracture density in the horizontal plane with sharp gradient across the main flow. For our applications it is important to maintain this flow-stripe structure and to avoid a smearing effect transversally to the flow, which can be associated with fracture healing for unphysical reasons. Figure 4 shows three transects perpendicular to the symmetry flow line in a simplified ice-shelf setup of $100 \mathrm{~km}$ width and length. Fracture density as a tracer is initialized with unity value within a small domain of $8 \mathrm{~km} \times 8 \mathrm{~km}$. Theoretically a narrow band of constant fracture density is expected downstream in a steady state. In fact, if the flow direction coincides with one grid axis, numerical diffusion can be neglected (Fig. 4b). However, the smearing effect depends on the direction of the flow with respect to the underlying grid. For the standard upwind scheme, it is strongest for diagonal transport (Fig. 4d), where finite differences towards the direct upstream neighbors are calculated (Fig. 3a), resulting in a "zigzag" course from cell to cell. This corresponds to a wide domain of influence of $90^{\circ}$, that is the triangle containing the two direct neighboring upstream grid cells, from where flux contributions are received. In order to increase the accuracy of the transport scheme, we split the domain of influence $\left(45^{\circ}\right)$ and consider eight different cases (instead of four in the standard case) depending on the flow direction. Thus, we calculate finite differences involving all eight neighboring grid cells,

$$
\begin{aligned}
& \phi_{\mathrm{N}+1}=\phi_{\mathrm{N}}-\Delta t . \\
& \qquad \begin{array}{ll}
u \frac{\phi_{i, j}-\phi_{i+1, j}}{\Delta x}+v \frac{\phi_{i+1, j}-\phi_{i-1, j-1}}{\Delta y}, & 0 \leq v \frac{\Delta x}{\Delta y}<u \\
u \frac{\phi_{i, j-1}-\phi_{i-1, j-1}}{\Delta x}+v \frac{\phi_{i, j}-\phi_{i, j-1}}{\Delta y}, & 0<u \frac{\Delta y}{\Delta x} \leq v \\
-u \frac{\phi_{i, j-1}-\phi_{i+1, j-1}}{\Delta x}+v \frac{\phi_{i, j}-\phi_{i, j-1}}{\Delta y}, & 0 \geq u \frac{\Delta y}{\Delta x}>-v \\
-u \frac{\phi_{i, j}-\phi_{i+1, j}}{\Delta x}+v \frac{\phi_{i+1, j}-\phi_{i+1, j-1}}{\Delta y}, & 0<v \frac{\Delta x}{\Delta y} \leq-u \\
-u \frac{\phi_{i, j}-\phi_{i+1, j}}{\Delta x}-v \frac{\phi_{i+1, j}-\phi_{i+1, j+1}}{\Delta y}, & 0 \geq v \frac{\Delta x}{\Delta y}>u \\
-u \frac{\phi_{i, j+1}-\phi_{i+1, j+1}}{\Delta x}-v \frac{\phi_{i, j}-\phi_{i, j+1}}{\Delta y}, & 0>u \frac{\Delta y}{\Delta x} \geq v \\
u \frac{\phi_{i, j+1}-\phi_{i+1, j+1}}{\Delta x}-v \frac{\phi_{i, j}-\phi_{i, j+1}}{\Delta y}, & 0 \leq u \frac{\Delta y}{\Delta x}>-v \\
u \frac{\phi_{i, j}-\phi_{i+1, j}}{\Delta x}-v \frac{\phi_{i+1, j}-\phi_{i+1, j+1}}{\Delta y}, & 0>v \frac{\Delta x}{\Delta y} \geq-u,
\end{array}
\end{aligned}
$$

where $N$ indicates the time step, while $i$ and $j$ are the coordinates on the regular rectangular grid, associated with the velocity vector components $u$ and $v$ (see Fig. $3 \mathrm{~b}$ ). The finite difference that corresponds to the smaller component of the vector velocity is simply shifted upstream. This modification exhibits less numerical diffusion for transport that is oblique with respect to the grid axes and hence preserves better the shape of stripe-like structures for advection in two dimensions. When turning the main flow direction by $45^{\circ}$, the higher order scheme reveals a much higher accuracy than in the unturned case. In contrast, for the first order scheme, maximum values are reduced by $60 \%$ of its initial value over a distance of $90 \mathrm{~km}$ (compare profile in Figs. $4 \mathrm{~d}$ and h). For the flow that is turned by intermediate angles (e.g., $22.5^{\circ}$ ), both schemes show an unintended numerical diffusion with a reduction of the maximum by about $50 \%$ for the standard upwind scheme and significantly less $(30 \%)$ for the improved accuracy scheme (Fig. 4c and g). Although, both schemes are not conservative, the integral along the considered cross sections varies less than $5 \%$ along the $90 \mathrm{~km}$ transport in a comparably smooth velocity field. Higher resolution increases the accuracy significantly for both schemes (Fig. 5), which needs to be considered in the experiments.

\subsection{Fracture formation along grounded ice streams}

Fractures are often observed to be initiated in the rocky shear margins of the inlets upstream from the grounding line, where ice flow accelerates due to decreased basal friction. The boundary condition for the fracture-density evolution, $\phi_{0}$, is applied along the grounding line that confines the ice shelf domain. In this way, $\phi_{0}$ accounts for pre-existing fractures draining through the inlets. We assume that fracture processes in grounded but "shelfy" regions occur under similar conditions as within the ice shelf domain. In this way we can calculate contributions to the fracture-density field from observed velocities in the grounded regions as prescribed boundary condition along the grounding line, yielding a more realistic $\phi_{0}$ than in a previous study (Albrecht and Levermann, 2012). 

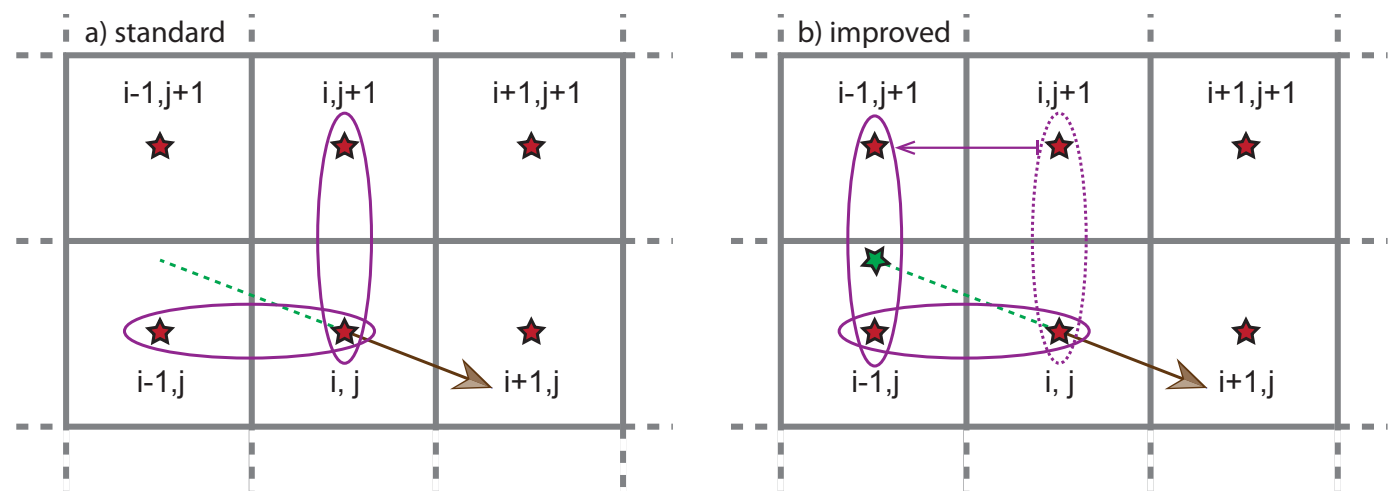

Fig. 3. Two-dimensional view of grid cell $i, j$ with a brown velocity vector pointing to the lower right cell neighbors $\left(0 \geq v_{i, j} \Delta x / \Delta y \geq\right.$ $-u_{i, j}$ ). The standard first-order upwind scheme takes into account the gradients along the two axes between the direct upstream neighboring cells (a). In order to gain a higher accuracy the second gradient is shifted upstream (violet arrow) (b). This improved scheme mimics a velocity-weighted gradient along the green-dashed flow line.
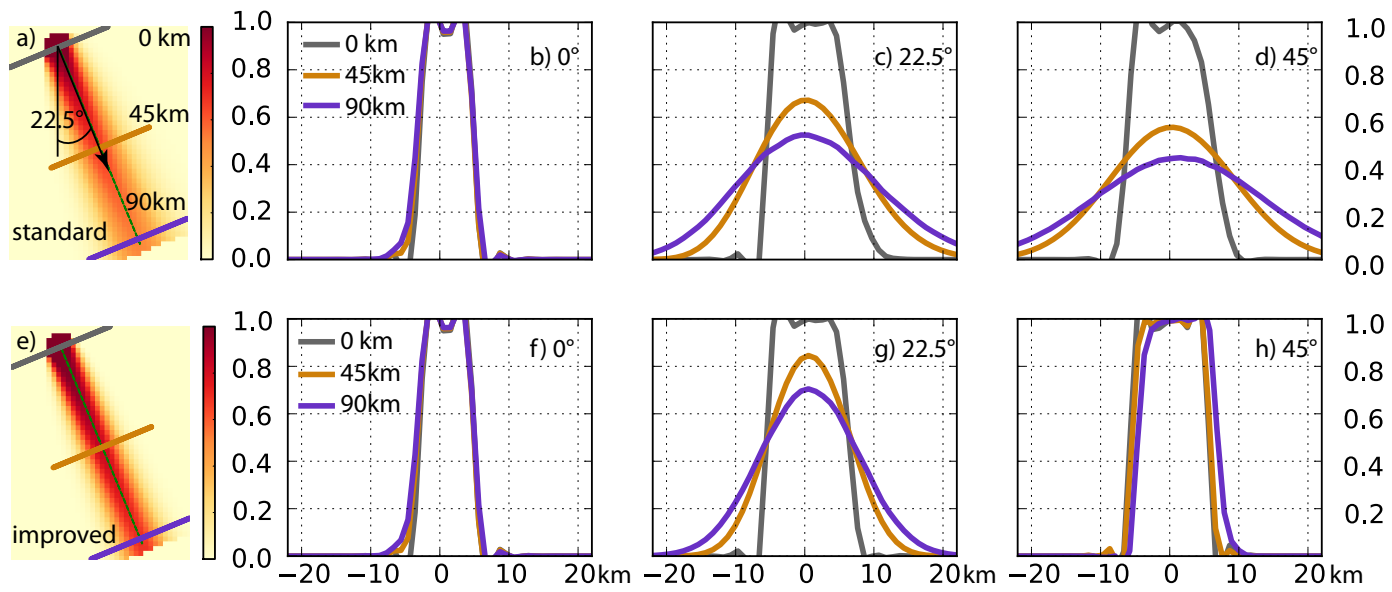

Fig. 4. Dissipation of fracture density during transport as studied in a simplified ice-shelf setup where the main flow direction is $0^{\circ}, 22.5^{\circ}$ and $45^{\circ}$ and oblique with respect to the underlying regular grid of mesh width $2 \mathrm{~km}$. The fracture band originates in a small spot with maximal fracture density $\phi=1$. Results shown in the top-panels are produced with the standard first-order upstream transport scheme, in the lower panels with the improved scheme. The steady-state cross-profile of the fracture band is compared at three transects perpendicular to the main flow direction at the source (grey), as well as with $45 \mathrm{~km}$ (brown) and $90 \mathrm{~km}$ (violet) distance, using bivariate interpolation for the plots.

\subsection{Interpreting fracture density from satellite visible imagery}

In order to compare the modeled fracture density with observations, we hand-digitized visible surface features that seem to represent fracture phenomena of any kind. We identified these features in MOA satellite spectroradiometer images of the largest Antarctic ice shelves as snapshot of the years 2003 to 2004 (Scambos et al., 2007, MODIS Mosaic of Antarctica). Recent observation have shown that observed surface troughs in ice shelves often correspond to widely spaced basal crevasses, which support surface fracturing by viscous-adjustment-induced bending effects (McGrath et al., 2012b; Luckman et al., 2012; Vaughan et al., 2012). However, the smaller surface crevasses as well as the highly fragmented shear zones are hard to identify from satellite data for resolutions of $150 \mathrm{~m}$, especially when snow-covered. Here we do not distinguish between the different representations (Glasser and Scambos, 2008; Glasser et al., 2009) and assume that visible fractures features have enough vertical extent to affect the flow dynamics, even though we do not consider the vertical distribution of voids in the ice column. Following Albrecht and Levermann (2012), we calculated a two-dimensional representation of the observed fracture features, $\phi_{\text {obs }}$, for each grid cell of a given resolution, assuming a rectangular "zone of influence" of $1 \mathrm{~km}$ width. This assumption is motivated by the fact that, for crevasse opening perpendicular to the the main tensile stress axis, the applied far-field stress has to circumvent the discontinuity. This reduces the effective stress to both sides of the crack, acting as a stress shadow cast. 

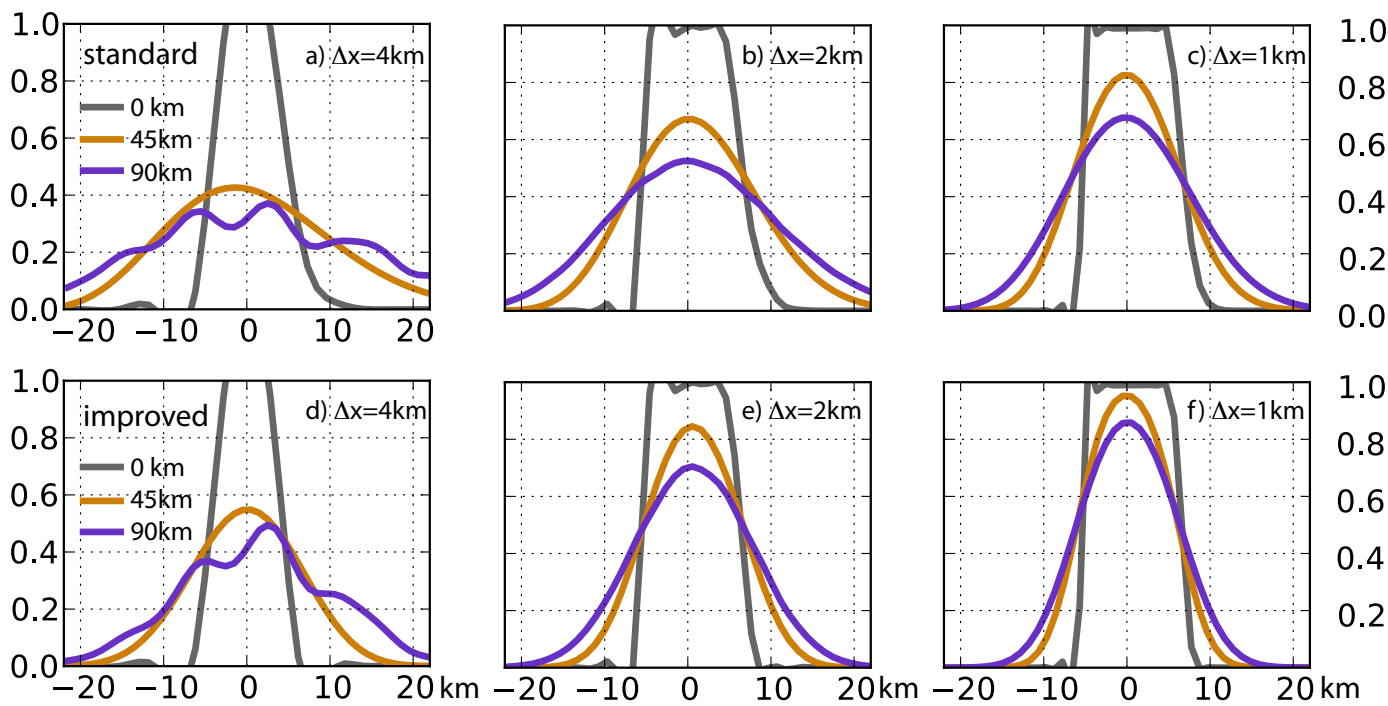

Fig. 5. Transport of fracture density as in Fig. 3 for different mesh sizes $4 \mathrm{~km}, 2 \mathrm{~km}$ and $1 \mathrm{~km}$ (left to right) where the main flow direction is turned by $22.5^{\circ}$ with respect to the underlying regular grid. Top panels show the results with the standard transport scheme; bottom panels show the ones done with the improved higher-accuracy scheme.

Additionally, the inferred observed fracture density was smoothed with a running mean along the flow line, which is derived from the modeled/observed velocity field. This along-flow-line spatial smoothing of the monitored snapshot mimics a time average and reveals more clearly the continuous band structure of observed fractures, for example, in suture zones and along shear margins (see Fig. 6). Apparently, this mapping procedure cannot give a precise and complete picture of the dynamically relevant observed fracture regions, but it gives an impression of the rough pattern of fracture abundance and fracture accumulation for a qualitative validation.

\subsection{Computational setup and settings}

The simulations of the Antarctic ice shelves that we performed are based on high-resolution data sets. Ice thickness, bed-topography data and the grounding-line position are described in the Bedmap2 product on a $1 \mathrm{~km}$ grid in polar stereographic projection (Fretwell et al., 2013). In order to avoid grounding in shallow ice-shelf areas, the sub-shelf seabed elevation is arbitrarily set to $2000 \mathrm{~m}$ depth. Climatic mass balance and ice-surface temperature are available from ALBMAP v1 on a $5 \mathrm{~km}$ grid (Le Brocq et al., 2010). FESOM data (melting and refreezing rates beneath the ice shelf), averaged over the historical period 1960 to 1999 , were kindly provided on an unstructured grid with resolutions of up to $4 \mathrm{~km}$ by Timmermann et al. (2012) and Timmermann and Hellmer (2013). A scaling parameter is used here to account for the FESOM subshelf mass flux data, which are prescribed and associated with a certain ice thickness distribution, while the PISM shelf-ice thickness can freely evolve in our setup. Surface-velocity data covering the whole Antarctic continent has been assembled by Rignot et al. (2011a) from multiple satellite interferometric radar data of the years 2007 to 2009. The data are used for validation and as Dirichlet boundary conditions along the grounding line (and in some subregions along the boundaries of the computational domain if the flow is directed inwards).

Since the data sets are a product of a period after the breakup of Larsen A and B ice shelves, the input data has been modified for this region according to a period prior to it (Jezek et al., 2003, Modified Antarctic Mapping Mission (MAMM)). Initial ice thickness in the embayment was inferred from surface elevation data on a $2 \mathrm{~km}$ grid with applied firn correction (Lythe et al., 2001). Provided MAMM surface velocities of the time period 1997-2000 for validation exhibit gaps that have been filled using an SOR method (successive over-relaxation) for the Laplace equation. For the inlets Dirichlet boundary conditions are based on the latest observations by Rignot et al. (2011a). Since the tributaries have accelerated after the collapse, the ice supply in the model for the intact Larsen B ice shelf may be overestimated. However, the objective of this study is a comparison between models rather than an optimal match to observations.

Iceberg calving is not considered in the simulations. The ice flow is simply cut off at the initial ice-shelf front. Friction along side margins and ice rises is not explicitly set as in previous studies since it inherently results from ice thickness and velocity along the boundary. Fracture initiation is considered also in the grounded region as determined by the prescribed velocities based on observations and is transported across the grounding line into the ice-shelf domain (see Sect. 4.3). Density within the ice is prescribed with a constant value of $910 \mathrm{~kg} \mathrm{~m}^{-3}$. A simplified computational 

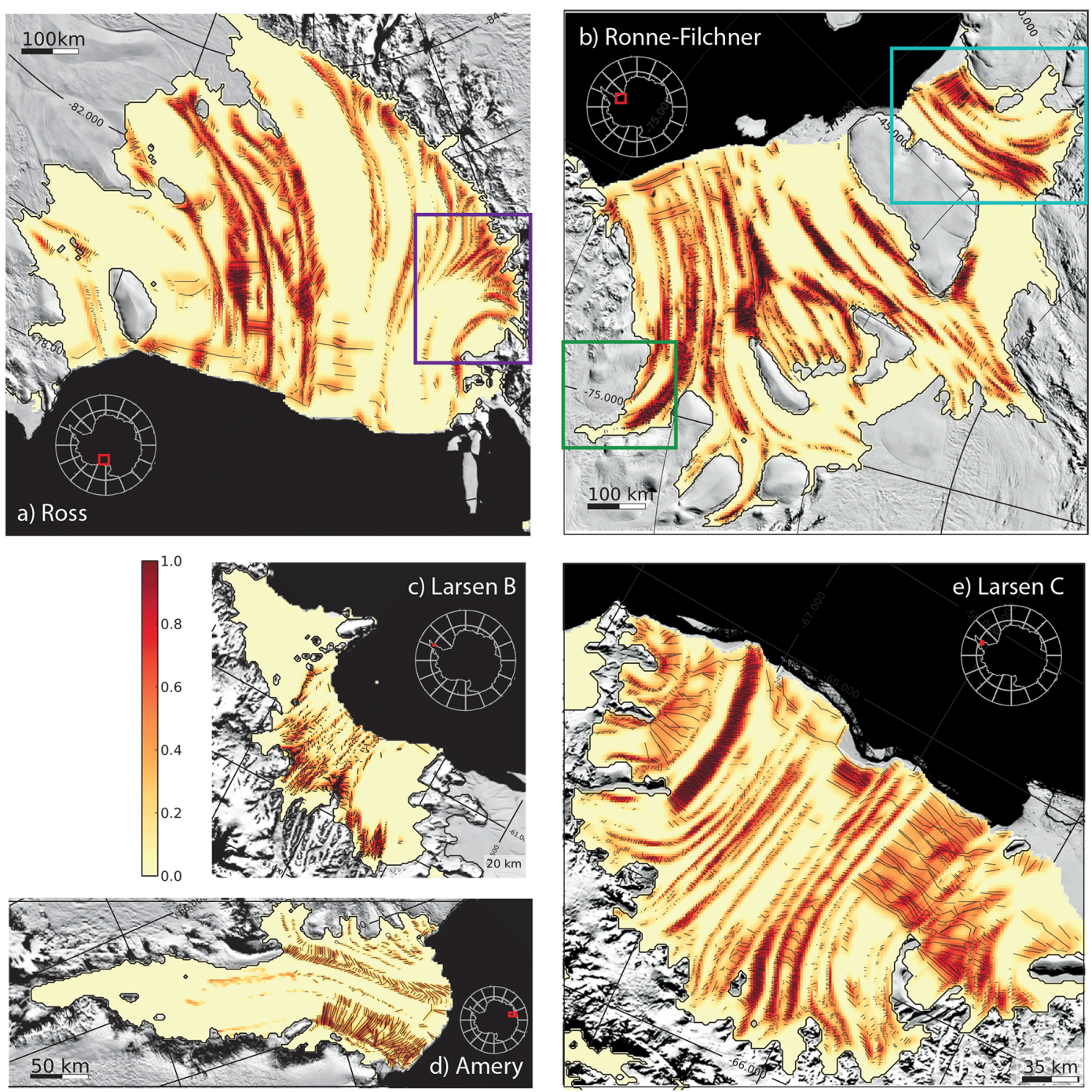

Fig. 6. Surface features in the largest and most important Antarctic ice shelves hand-digitized from MODIS data (Scambos et al., 2007, Mosaic of Antarctica). Positions of ice shelves are marked in the inset Antarctica map. Smoothed observed fracture density $\phi_{\text {obs }}$ is shaded in orange/red colors across the ice shelf surrounded by MOA image map of grounded landscape and ice-free ocean. Colored rectangles show areas of investigated regional setups.

setup is used with an ice shelf confined in a rectangular bay of $100 \mathrm{~km}$ width and $2000 \mathrm{~m}$ depth. Constant ice inflow is defined at the upper grounding line with $600 \mathrm{~m}$ thickness and $300 \mathrm{~m} \mathrm{yr}^{-1}$ speed while the friction along the side margins is prescribed, such that the intensity of shear flow can be controlled. Surface temperature is constantly $-30^{\circ} \mathrm{C}$ and at pressure melting point at the base. Surface-mass balance is constantly $0.1 \mathrm{~m} \mathrm{yr}^{-1}$ on the ice shelf. The minimum resolution is $1 \mathrm{~km}$ in this simplified setup, which can be simply rescaled to coarser multiples of that resolution.

\section{Results}

\subsection{Self-amplified fracturing}

Non-linear systems may exhibit bistable phenomena based on a positive, that is, self-amplifying, feedback mechanism as considered previously in the text (Sect. 3). On large climatic scales, systems that exhibit such behavior are sometimes called "tipping elements" (Levermann et al., 2011). Here this characteristic threshold behavior is investigated in a simplified experiment, where fracture density of $\phi=0.7$ is prescribed within a confined ice shelf region (a few grid cells), which imitates a constantly active fracture source (similar to setup in Fig. 4). The ice flow carries away damaged ice from this constant supply forming a fracture band 

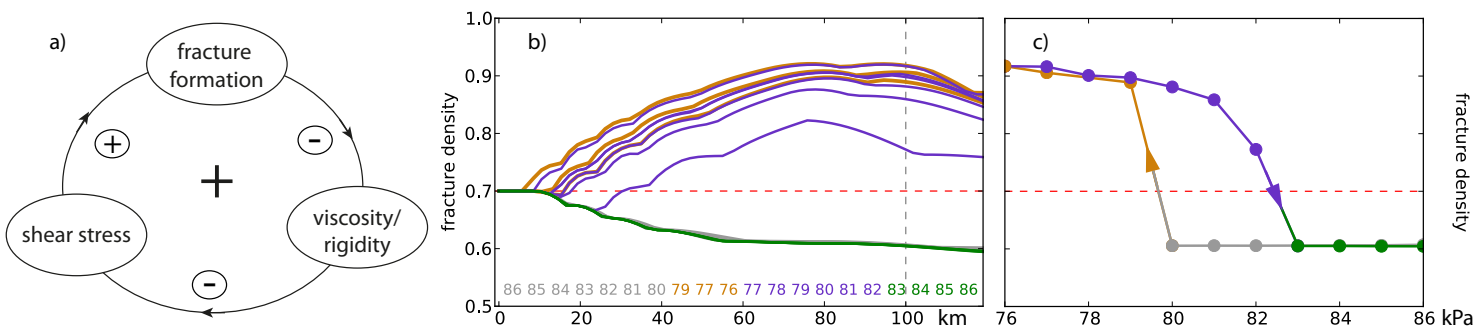

Fig. 7. The self-amplifying feedback (a) is studied in a simplified ice-shelf setup for successively varied fracture-initiation threshold $\sigma_{\mathrm{cr}}$. Corresponding steady-state fracture-density profiles along the flow line are shown in rainbow colors (b). Each profile initiates at the point of prescribed value $\phi=0.7$ at the left hand side. Fracture density accumulates or decays with distance from this point depending on the specific threshold. The black vertical line indicates the position $100 \mathrm{~km}$ downstream, where values are taken for hysteresis plot (c). Two steady-state fracture densities exist between $79 \mathrm{kPa}$ and $83 \mathrm{kPa}$ depending on the previously evaluated threshold.

elongated with the flow. If a high critical threshold for fracture growth, $\sigma_{\mathrm{cr}}$, is chosen, no additional fractures will form, resulting in a steady-state fracture band of constant or slightly decreasing density with distance from the supply (see red and blue profiles in Fig. 7b). In this experiment we consider a shearing flow regime, where effective stresses can locally reach up to $80 \mathrm{kPa}$. We gradually reduce the critical threshold $\sigma_{\mathrm{cr}}$, mimicking an additional environmental forcing that supports fracture formation (e.g., by meltwater infiltration). If it goes below $\sigma_{\mathrm{cr}}=80 \mathrm{kPa}$, additional fractures can form, which softens the ice locally allowing for enhanced shear flow. This is a self-amplifying feedback mechanism (Fig. 7a), which also influences the region downstream of this spot. Advected fracture density leads to higher effective shear stresses and can accumulate on its course along the flow, as indicated by the upper profiles in Fig. $7 \mathrm{~b}$.

If environmental conditions reverse, such that the fracture threshold $\sigma_{\mathrm{cr}}$ increases, we observe a jump back to the off mode for critical thresholds of $\sigma_{\mathrm{cr}}>82 \mathrm{kPa}$, which is larger than the value, where self-amplification was switched on $\left(\sigma_{\mathrm{cr}}<80 \mathrm{kPa}\right)$. Hence, this switch between the two stable states occurs at different levels of the control parameter due to the memory of the system, which can be interpreted as hysteresis behavior (Fig. 7c). This is a robust feature and is also found in more realistic setups representing relevant Antarctic ice shelves.

\subsection{Application to Antarctic ice shelves and subregions}

In the following the various aspects of fracture-softening are investigated in examples of ice shelf sub-regions of the largest Ross and Ronne-Filchner ice shelves (see colored rectangles as computational boundaries in Fig. 6). The smaller northern-most Larsen ice shelves along the Antarctic Peninsula will be discussed as separate case. Simulations are performed on a $1 \mathrm{~km}$ regular grid. Parameters for the standard run are estimated on the basis of an ensemble analysis minimizing the root mean square error (RMSE) of both ice thickness and ice speed compared to observations. However, this study does not intend to find the best possible fit, but to investigate the qualitative changes of the ice flow induced by the employed fracture feedback for each individual setup.

\subsubsection{Byrd inlet in Ross Ice Shelf}

The Byrd inlet is an important inflow for the Ross Ice Shelf, draining though a narrow trough of the Transantarctic Mountains (Fig. 8a). From there the ice flows as a homogeneous unit at about $600 \mathrm{~m} \mathrm{yr}^{-1}$ eastwards through slow moving ice that is confined within the embayment of Ross Island. The cross section right after the entrance of the inlet shows steep velocity gradients especially on the northern side. A constant flow enhancement $E_{\mathrm{SSA}}=0.05$ yields a RMSE of about $95 \mathrm{~m} \mathrm{yr}^{-1}$ for simulations of the whole Byrd inlet domain, where the standard model underestimates velocities in the inner inlet and overestimates them closer to the margins respectively. The corresponding profile perpendicular to the main flow direction hence shows a smooth transition between the broad inflow unit and the much slower surrounding ice (light blue in Fig. 8c), but it does not allow for the intense observed shear gradient. In contrast, fracture-softening reveals highly fractured bands on both sides of the inlet (Fig. 8b), confining the fast flow unit, with sharp gradients at its flanks (violet profile in Fig. 8c). Yet, the resulting profile appears to be shifted transversally by about $15 \mathrm{~km}$, with a slightly larger RMSE, which is not a good measure here. This shift might be caused by underestimated inflow through the southern boundary of the computational domain, forcing the incoming stream northwards. The orange contour lines in Fig. 8b indicate that fractures form already in the grounded upstream inlet channel, where the von-Mises effective stress is larger than $110 \mathrm{kPa}$. This fracture band partly detaches the flow from the topographical promontory further downstream $(\mathrm{Pr})$, which otherwise would act as fracture-formation area. Healing is comparably small but fracture density vanishes within about $100 \mathrm{~km}$ distance as suggested by observations in this area. 


\subsubsection{Evans inlet in Ronne Ice Shelf}

The ice stream of the Evans Glacier enters the second largest Ronne Ice Shelf in the west and turns north. This motion yields an inclined cross profile with a speed of up to $700 \mathrm{~m} \mathrm{yr}^{-1}$ at the souther margin jumping to almost $100 \mathrm{~m} \mathrm{yr}^{-1}$ in some minor side inlets (green profile in Fig. 9d). Simulations with the ordinary stress balance require a small basic flow enhancement $E_{\mathrm{SSA}}=0.05$ (light blue in Fig. 9c and d), in order to reproduce observed surface velocities in this region (RMSE: about $100 \mathrm{~m} \mathrm{yr}^{-1}$ ). However, neither the gradual inclination of the main flow nor the strong gradient at the southern flank are well represented. Fracture softening instead exhibits these features and produces a thin fracture band along the rocky margin. From there the fracture zone continues with the main flow and separates the stagnant regions at the sides (right hand side in Fig. 9d). A relatively high critical threshold stress of $140 \mathrm{kPa}$ and a comparably strong healing in the main trunk of the inlet limits the extent of the fracture band and restricts the inflow in the observed range. Observations confirm the presence of elongated fragmental structures close to the margin from where crevasses propagate towards the center line of the inlet. On average ice speed in the ice shelf domain agrees much better with observations (see RMSE reduced by $6 \%$ and maps of velocity anomalies are provided as Supplement).

\subsubsection{Filchner Ice Shelf}

Filchner Ice Shelf is the fastest of the smaller Antarctic ice shelves with speeds up to $1400 \mathrm{~m} \mathrm{yr}^{-1}$ close to the front (Fig. 10a). It shears along Berkner Ice Rise (BIR) at its western margin and drains into the Weddell Sea in the north. The cross section is located south of the rifted areas at the northeastern margin (cf. Figs. $6 \mathrm{~b}$ and 10c). The maximum speed is shifted from the center line towards the Berkner side with a small buckle at about $70 \mathrm{~km}$ distance. This feature likely indicates the presence of a suture zone between the flow unit fed by the Recovery Glacier and the flow coming from the Support Force Glacier farther west. The characteristic flow pattern in relation to observed surface crevasses was already diagnostically studied by Saheicha et al. (2006), presuming a crevasse band with origin at Recovery Glacier inlet (see overlain structures in Fig. 10b). Simulations with constant enhancement factor $E_{\mathrm{SSA}}=0.2$ produce a symmetric and smooth velocity distribution (RMSE: $145 \mathrm{~m} \mathrm{yr}^{-1}$ ) within the Filchner trough (light blue in Fig. 10c). A much better representation of elongated structures such as the suture zone within the main trunk causing a small kink in the velocity profile is provided by application of the fracture-softening scheme with a relatively high critical stress threshold of $130 \mathrm{kPa}$. For chosen parameters a better agreement with observations is attained than in the standard model (RMSE: $100 \mathrm{~m} \mathrm{yr}^{-1}$ ), reproducing much of the inclination and the steep gradient at the western margin. The straight inclined part of the observed profile might be an effect of the rift system downstream, which is not accounted for in the model.

The characteristic fracture band pattern is also obtained for lower resolution of $2 \mathrm{~km}$ or even $5 \mathrm{~km}$ (Fig. 11); however, much more damped for wider meshes (cf. Fig. 5). Hence the softening effect is weaker and the typical shape of the across velocity profile is less pronounced.

\subsubsection{Larsen B region prior to its break-up}

The Larsen B ice shelf is situated at the northeastern flank of the Antarctic Peninsula facing the Weddell Sea (Fig. 12). The climatic conditions in this region are considerably different from those in the more continental ice shelves farther south. Surface melting during summer can produce melt ponds (Glasser and Scambos, 2008), which initiate a series of processes that can result in such large-scale events as the disintegration of major parts of Larsen B in 2002 within a few weeks (Rack and Rott, 2004). Satellite observations indicated a heavily crevassed ice-shelf surface prior to the collapse (Fig. 6c) and model studies confirmed the dynamically active role of those fractured regions (Sandhäger, 2003; Sandhäger et al., 2005; Vieli et al., 2006, 2007; Khazendar et al., 2007; Borstad et al., 2012). Since ordinary model configurations with constant flow enhancement fail to accurately reproduce the characteristic pre-collapse flow pattern with sharp velocity gradients across weak shear zones along the side margins of the Larsen B regime (cf. green profile in Fig. 12), our fracture-density approach provides a physically motivated tool to reduce this discrepancy. The velocity of the interior of the ice shelf appears plateau-shaped. This can be explained by the partial mechanical decoupling from the confining side margins such that a large enhancement factor of $E_{\mathrm{SSA}}=10$ is needed to reach observed maximum velocity values of up to $560 \mathrm{~m} \mathrm{yr}^{-1}$ along the central front (cf. dashed light blue in Fig. 12e). Especially along inlets close to the grounding line the computed velocities are far too small (Fig. 12f).

A fracture-density dependent and hence spatially varying flow enhancement reproduces the observations much better (thick violet in Fig. 12e and f), since the inferred fracture density identifies the dynamically relevant weak zones and allows for intense located softening and hence strong flow gradients. In this example, fracture-density-induced ice weakening occurs not only along the side margins, but also along a wide fracture band further downstream. Inversely inferred damage in Larsen B based on the short observation period identifies similar band structures (Borstad et al., 2012, Fig. 1d).

We used an enhancement factor $E_{\mathrm{SSA}}=1.0$ as base level for unfractured ice, which is more realistic for ice shelves in tension than values larger than 1 (Ma et al., 2010). A comparably high value for the fracture rate $\gamma=1.0$ and a low value of the fracture-initiation threshold $\sigma_{\mathrm{cr}}=60 \mathrm{kPa}$ is needed in order to yield high fracture-density accumulation 

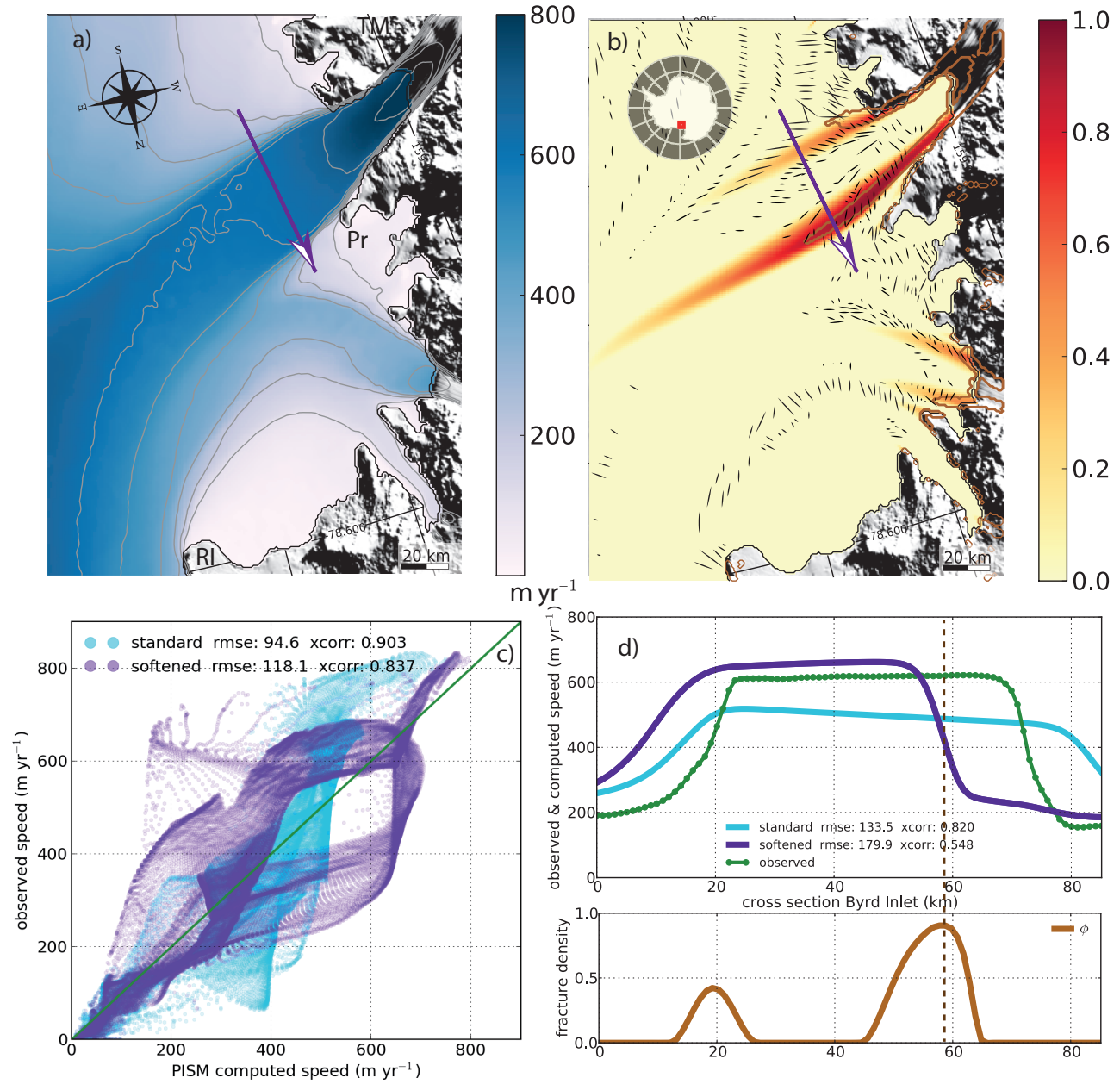

Fig. 8. Observed surface speed of the years 2003 and 2004 (a) and modeled steady-state fracture density $\phi$ (b) for the Byrd inlet region in western Ross Ice Shelf (violet box in Fig. 6 a). In the lower panel values of observed (green) and calculated ice speed (blue and violet) as well as corresponding fracture density (brown) are plotted along indicated cross section. Parameters: FESOM-melting factor $0.2, E_{\mathrm{SSA}}=0.05$, $\gamma=0.2, \sigma_{\mathrm{cr}}=110 \mathrm{kPa}, \gamma_{\mathrm{h}}=0.05, \dot{\epsilon}_{\mathrm{h}}=20 \times 10^{-10} \mathrm{~s}^{-1}$.

close to unit value and hence strong softening in the active regions. Especially within the narrow tributary inlets, densely spaced fractures and hence intense softening occurs, which coincides with detailed observation in theses areas (Glasser and Scambos, 2008, Fig. 2). Surface meltwater draining into existing crevasses and enhancing fracture formation support this parameter choice. On the other hand, for accumulation rates of more than $1 \mathrm{~m} \mathrm{yr}^{-1}$ and possibly refreezing within surface and bottom crevasses, strong healing $\gamma_{\mathrm{h}}=2.0$ may be plausible. Self-enforcing fracture growth occurs, due to the low initiation threshold, in a large portion of the Larsen B ice shelf, such that the location of fracture-free regions from those of highly fractured ones depends sensitively on the applied healing threshold (here $\dot{\epsilon}_{\mathrm{h}}=6 \times 10^{-10} \mathrm{~s}^{-1}$ ).

\section{Discussion}

Fractured regions can support only limited stress and lose this ability when crossing a specific threshold. Fractureinduced softening has the potential to introduce additional non-linear characteristics into the ice-flow dynamics such as dynamic regime shifts (bifurcation), hysteresis behavior and irreversibility. This has been investigated for a shear zone in steady-state configurations with respect to successively varied parameters (Fig. 7). A self-amplifying process is then activated and additional fractures intensify the shear, which in turn promotes additional fracturing. Hence, small changes in environmental conditions potentially have strong impacts in such systems. A short surface-melting period can trigger a change in fracture threshold and may activate such abrupt shifts between dynamic regimes. This mechanism is robust and may occur for different settings at different thresholds. Critical effective stresses of $80 \mathrm{kPa}$ as in 

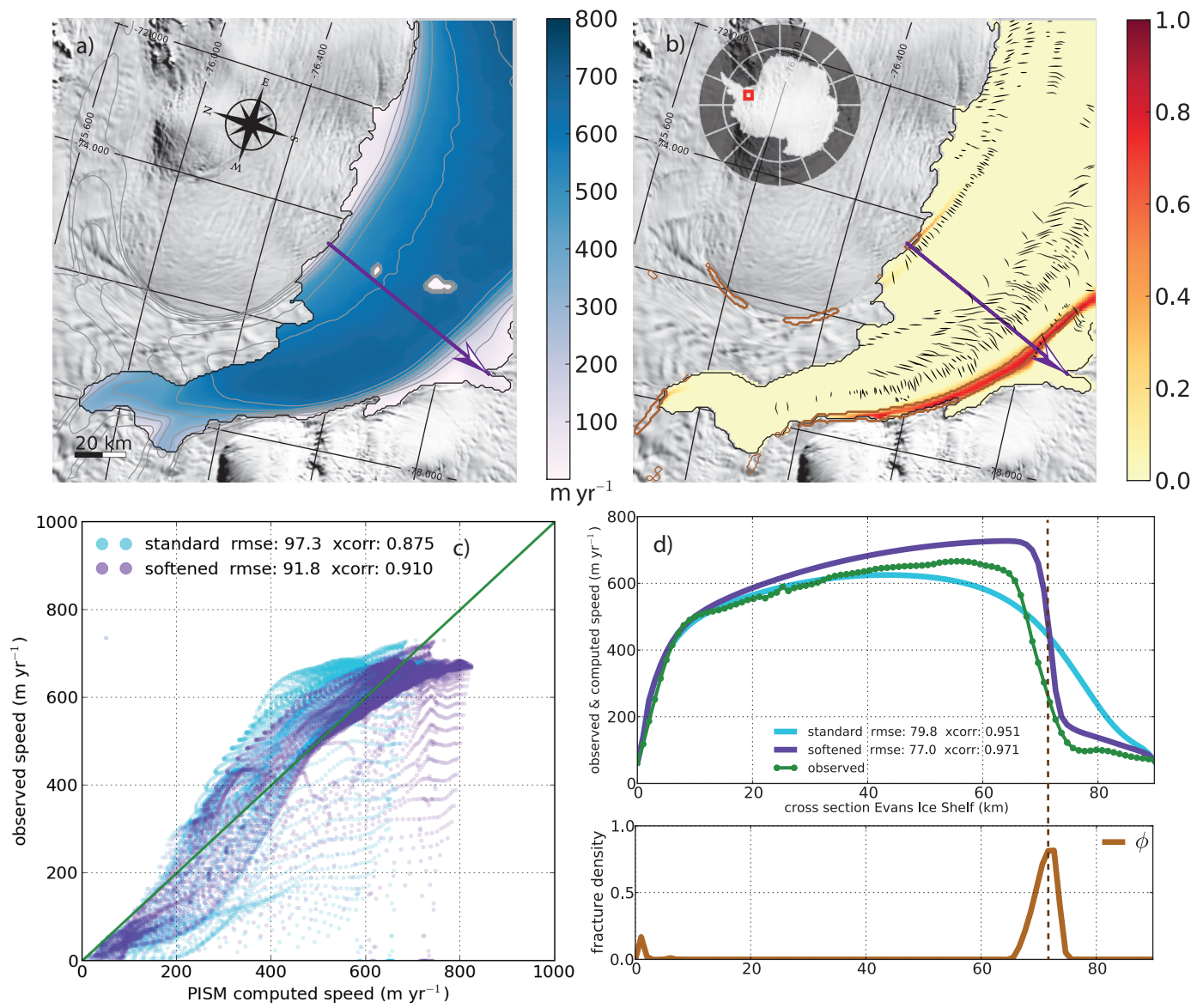

Fig. 9. Observed surface speed (a) and calculated fracture density (b) in the Evans inlet in western Ronne Ice Shelf (green box in Fig. 6 b). In the lower panels values of observed (green dots) and calculated ice speed are presented, light blue for the constant flow enhancement, violet for fracture-induced softening. Corresponding fracture density (brown) is plotted along the indicated cross section. Parameters: FESOMmelting factor $1.0, E_{\mathrm{SSA}}=0.05, \gamma=0.2, \sigma_{\mathrm{cr}}=140 \mathrm{kPa}, \gamma_{\mathrm{h}}=0.1, \dot{\epsilon}_{\mathrm{h}}=12 \times 10^{-10} \mathrm{~s}^{-1}$.

the demonstrated simplified case are found at the lower end of the observation-derived critical-value range with values reaching up to $320 \mathrm{kPa}$ (Vaughan, 1993). This large range indicates a high variability of fracture histories, temperature regimes, ice properties but also uncertainty in the conversion of measurable strain-rates to stresses. Hence, stress thresholds are not constant material parameters and may differ depending on various conditions.

However, independent of this qualitative possibility of non-linear threshold behavior, we find that the influence of fractures on the creep of ice is relevant in a number of situations. This study does not aim at a conclusive investigation of the influence of fracture on the flow field. It is rather meant to introduce the first-order concept and to provide results on the qualitative changes in the flow field when fracture density is accounted for in this way. The critical strengths for the realistic computational setups of Antarctic ice shelves and ice shelf inlets were determined such that characteristic observed flow patterns are adequately represented, which provides a rough way of parameter calibration. The so estimated critical values for parts of the large Antarctic ice shelves are located in the lower half of this literature range, i.e., 110-140 kPa (Figs. 810). Only shear stresses can reach these high thresholds in the presented applications. In contrast a comparably low threshold of $60 \mathrm{kPa}$ has to be chosen in the smaller Larsen B ice shelf situated at the Antarctic Peninsula (Fig. 12) in order to produce realistic fracture and flow patterns. This cannot be just explained just by temperature effects, since the decrease in fracture toughness for increasing temperatures is comparably small (about $-0.5 \mathrm{kPam}^{-1 / 2}{ }^{\circ} \mathrm{C}^{-1}$ according to Schulson and Duval, 2009, Fig. 9.4). Ice-shelf thickness and the associated confining cryostatic stress may explain some of this variance, that would reduced for a non-dimensional threshold (Bassis, 2011).

Using higher thresholds in the Larsen B simulation cannot produce the degree of fracture density within the evolving fracture bands, which is necessary to capture the observed strong shearing for the given setting of enhancement factor and healing parameters, $E_{\mathrm{SSA}}, \gamma_{\mathrm{h}}$ and $\dot{\epsilon}_{\mathrm{h}}$ respectively. External conditions like melt water draining into surface crevasses 



Fig. 10. Observed surface speed over MODIS data (a) and calculated fracture density (b) in the Filchner Ice Shelf (light blue box in Fig. 6 b). Scatter plot of computed vs. observed velocities (c) for constant flow enhancement (blue) and in the fracture-softened case (violet). Corresponding cross sections of observed and calculated ice speed as well as fracture density are shown in the lower right panel (d). Parameters: FESOM-melting factor $1.0, E_{\mathrm{SSA}}=0.2, \gamma=0.3, \sigma_{\mathrm{cr}}=130 \mathrm{kPa}, \gamma_{\mathrm{h}}=0.02, \dot{\epsilon}_{\mathrm{h}}=15 \times 10^{-10} \mathrm{~s}^{-1}$.

or basal melting intensified within basal crevasses openings provide reasonable explanations for a considerably lower threshold in this region. However, this study is not meant as a parameter-tuning exercise and the inferred parameters should be considered with caution. Generally, for increasing basic enhancement factor $E_{\mathrm{SSA}}$, stresses are intensified throughout the ice shelf domain and thresholds are more likely met at stress maxima. Related ice-shelf thinning is not further discussed here. The signal of fracture softening in ice thickness is much less pronounced than in flow speeds. A comparison to the damage effect patterns inferred by inverse methods from observed surface velocities (Borstad et al., 2012, Fig. 1d) indicates a good match along the margins of Larsen B ice shelf and in the vicinity of its inlets. However, this pattern reveals the macroscopic effect of damage within a short time period, while certain fractured regions may be dynamically inactive.

In our study we used the von-Mises criterion, which identifies preferably fracture initiation in shear regions. These regions coincide with observed fracture features at the ice shelf surface (Fig. 6), but crevasse bands in rather tensile flow regimes are not well reproduced. We have shown that more sophisticated mixed-mode criteria based on LEFM do not change the results significantly, at least for large-scale simulations of ice shelves. Since tensile crevassing occurs predominantly in pre-fractured ice, we do not distinguish between the particular failure behavior and assume a smooth transition of ductile to brittle fracturing. In the present formulation we account for horizontal interactions simply parameterized by a factor $(1-\phi)$ in Eq. (2), bounding the evolving fracture density. However, this integrated view neglects the vertical extent and possibly non-linear interactions of basal and surface crevasses (McGrath et al., 2012b, a; Luckman et al., 2012; Vaughan et al., 2012). In fact, resolving the vertical dimension of fracturing is relevant in understanding fracture interaction and calving and needs to be specified in an expanded formulation of the fracture density. To give an example, tensile crevasse formation at the ice-shelf bottom triggered by vertical bending at the grounding line (Logan et al., 2013) cannot be captured by shallow approximation models. Contribution of such processes may be considered as boundary conditions, $\phi_{0}$, in future studies. Considering the involved vertical bending stresses, tidal flexure seem to play a secondary role.

With origin in the fracture formation areas, elongated damage bands often reach far downstream towards the front. 

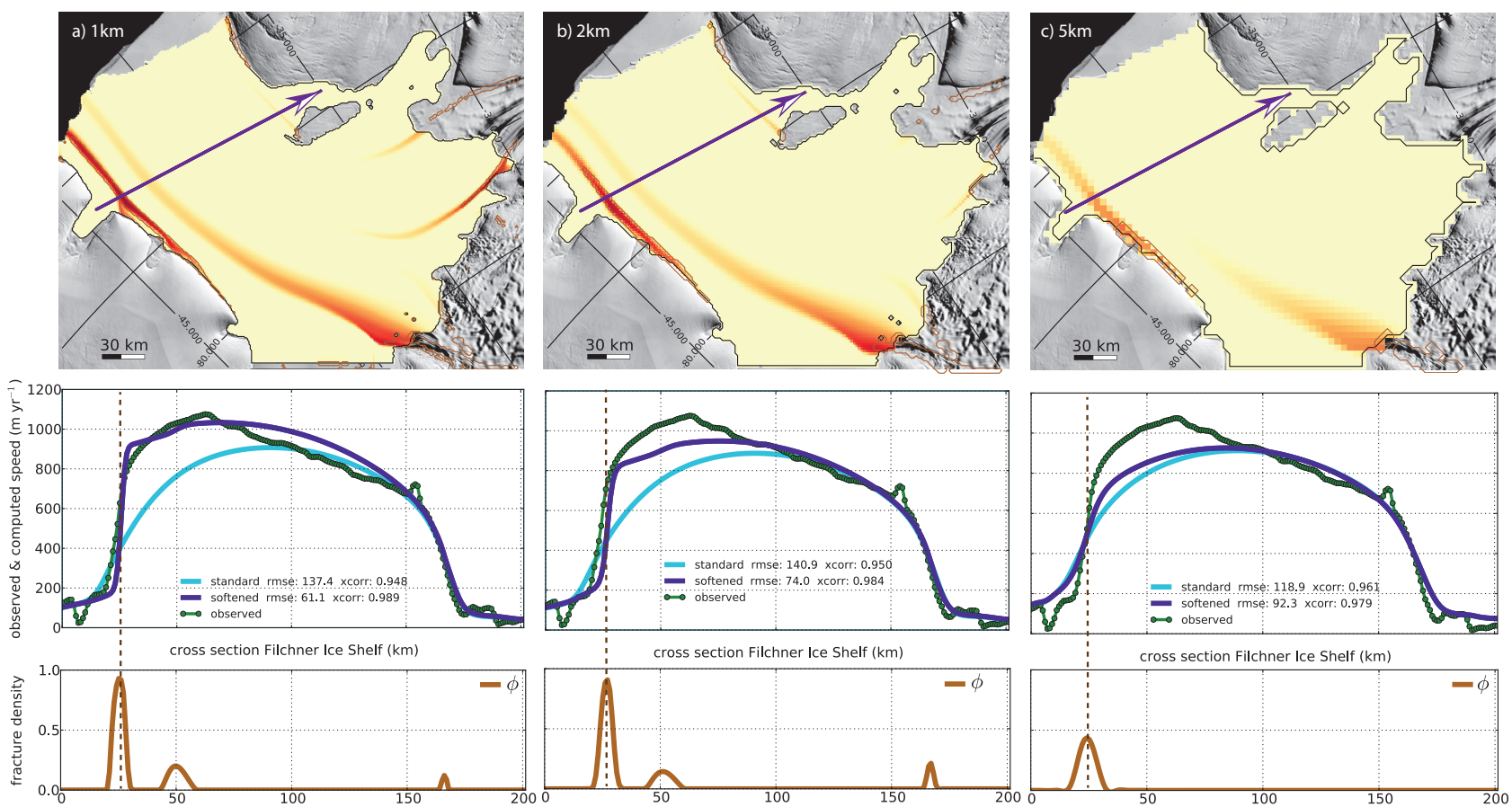

Fig. 11. Calculated fracture density in the Filchner Ice Shelf for varied resolutions $1 \mathrm{~km}, 2 \mathrm{~km}$ and $5 \mathrm{~km}$ from left to right. In the lower panels values of observed and calculated ice speed as well as the corresponding fracture density are plotted along the indicated cross section. Parameters same as in Fig. 10.

Viscosity is reduced along these confined fractured zones assuming a linear relationship, comprising all relevant softening processes. This procedure mimics a partial mechanical decoupling of the separated regions and reproduces a couple of observed flow characteristics: fast-flowing units of the ice shelf pass by stagnant ice shelf regions in minor side bays (Figs. 9 and 12) or get sutured together with neighboring flow units of different speed. This can be identified by jumps or kinks in ice-speed cross sections (Figs. 8 and 10). Ice-stream inlets shearing along the rocky fjord walls accelerate when the main flow gets partly detached from the sticky margins (Fig. 9). Similar effects are observed within small ice shelves shearing along islands or ice rises. Along these fractured zones of weakness transversal stresses cannot be transferred effectively leading to increased speed and less buttressing.

This prognostic fracture-density approach might be expanded, especially regarding the application to grounded ice streams as well as to the coupling of the evolving fracture density in an enhanced calving scheme. A natural link exists already in the given framework between fracture-induced modification of internal stresses and the strain-rate-based calving scheme (Levermann et al., 2012), but this is beyond the scope of this study.

\section{Conclusions}

We developed a phenomenological scalar fracture-density evolution model coupled to viscous-creep deformation in shallow approximation. This formulation, based on firstorder assumptions as simplified version of the more general continuum damage model, captures the gross interactions of flow dynamics and fracture processes. The aim of this study is to represent characteristic ice-flow behavior at the macroscale and to roughly constrain involved parameters using satellite data. Its implementation into a conventional ice sheet and ice shelf model is straight forward. An enhanced transport scheme improves the representation of the fracturedensity advection. This framework provides a basis for more rigorous formulations requiring more detailed experimental laboratory and field data for model validation. Furthermore the fracture-density approach provides a spatial and temporal link between local fracture initiation and post-formation processes occurring on the large scale and eventually located elsewhere. Rift propagation and calving would be examples of such phenomena. Hence, the structural integrity and stability of key regions, buttressing the ice flow, can be evaluated in a more realistic manner and potential contributions to global sea level can be assessed with more confidence. 

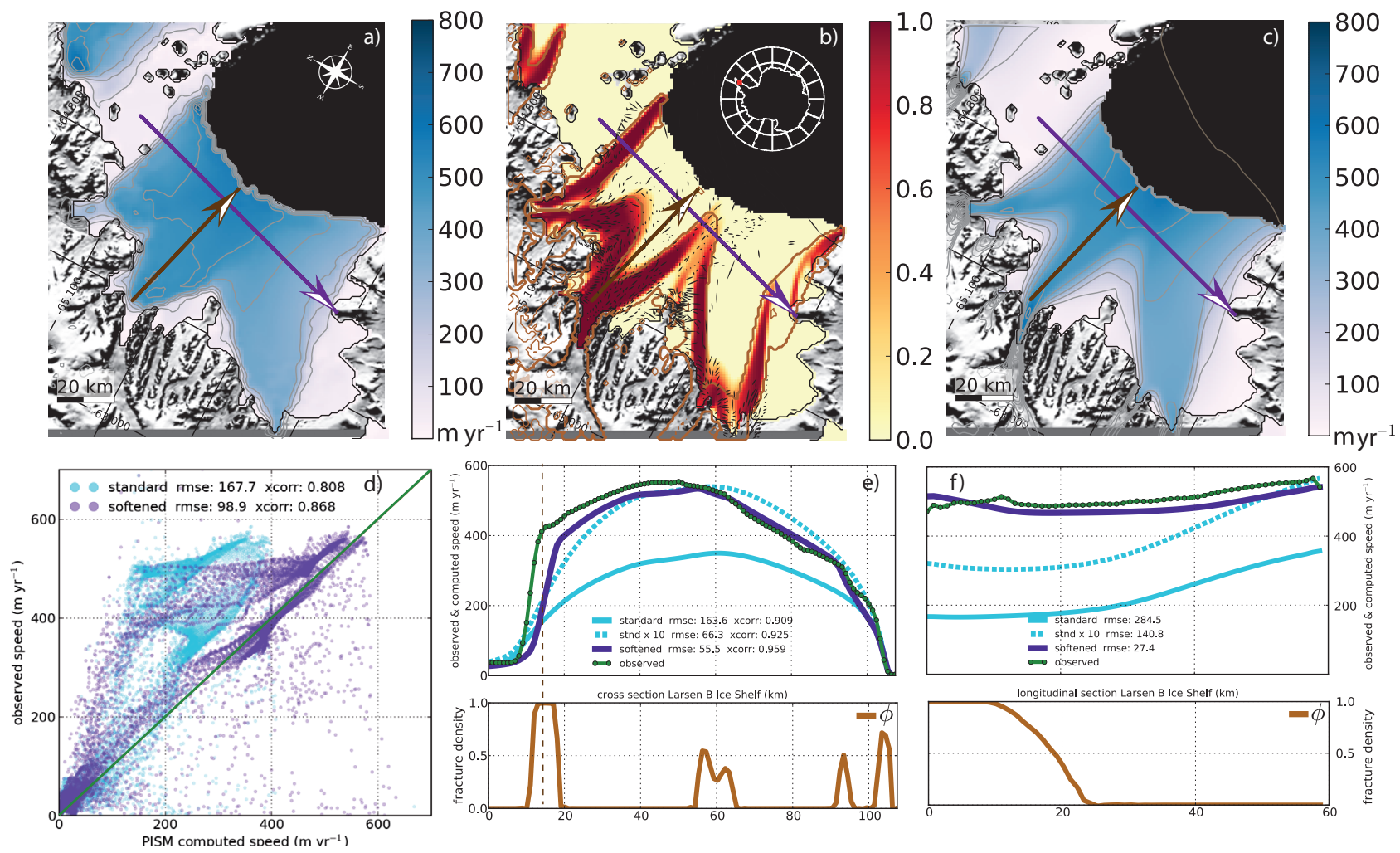

Fig. 12. Observed surface speed of the years 1997 to 2000 as well as calculated fracture density and ice speed in the Larsen B ice shelf (a-c). Point-by-point correlation of calculated and observed ice velocities in the lower left panel (light blue for constant enhancement factor and violet with fracture softening). (e-f) demonstrate the effect of the coupled fracture density on the calculated ice speed (cf. light blue, dashed and violet) compared to observed speeds (green) along the indicated transverse section (violet arrow) and longitudinal section (brown arrow). Parameters: FESOM-melting factor $0.2, E_{\mathrm{SSA}}=1.0, \gamma=1.0, \sigma_{\mathrm{cr}}=60 \mathrm{kPa}, \gamma_{\mathrm{h}}=2.0, \dot{\epsilon}_{\mathrm{h}}=6 \times 10^{-10} \mathrm{~s}^{-1}$.

\section{Supplementary material related to this article is available online at http://www.the-cryosphere.net/8/587/ 2014/tc-8-587-2014-supplement.zip.}

Acknowledgements. We thank E. Bueler, C. Khroulev and D. Maxwell (University of Alaska, USA) for a great collaboration and technical assistance with the Parallel Ice Sheet Model (PISM), development of which is supported by NASA grants NNX09AJ38C, NNX13AM16G, and NNX13AK27G. We are grateful for stimulating discussions with G. Jouvet. We also thank M. Mengel for preprocessing various data sets. R. Timmermann kindly provided FESOM sub-shelf melting data and N. Glasser detailed observational surface feature maps of the Larsen ice shelves. Ultimately, we appreciate the very constructive review comments by J. Bassis, C. Borstad and an anonymous referee, which essentially improved the manuscript. T. Albrecht was funded by the German National Merit Foundation (Studienstiftung des deutschen Volkes).

Edited by: E. Larour

\section{References}

Albrecht, T. and Levermann, A.: Fracture field for large-scale ice dynamics, J. Glaciol., 58, 165-176, doi:10.3189/2012JoG11J191, 2012.

Bamber, J. L. and Aspinall, W. P.: An expert judgement assessment of future sea level rise from the ice sheets, Nat. Clim. Change, 3, 424-427, doi:10.1038/nclimate1778, 2013.

Bamber, J. L., Riva, R. E. M., Vermeersen, B. L. A., and LeBrocq, A. M.: Reassessment of the Potential Sea-Level Rise from a Collapse of the West Antarctic Ice Sheet, Science, 324, 901-903, doi:10.1126/science.1169335, 2009.

Bassis, J. N.: The statistical physics of iceberg calving and the emergence of universal calving laws, J. Glaciol., 57, 3-16, 2011.

Bassis, J. N. and Jacobs, S.: Diverse calving patterns linked to glacier geometry, Nat. Geosci., advance online publication, doi:10.1038/ngeo1887, 2013.

Bassis, J. N., Fricker, H. A., Coleman, R., and Minster, J. B.: An investigation into the forces that drive ice-shelf rift propagation on the Amery Ice Shelf, East Antarctica, J. Glaciol., 54, 17-27, 2008.

Benn, D. I., Warren, C. R., and Mottram, R. H.: Calving processes and the dynamics of calving glaciers, Earth-Sci. Rev., 82, 143179, 2007. 
Borstad, C. P., Khazendar, A., Larour, E., Morlighem, M., Rignot, E., Schodlok, M. P., and Seroussi, H.: A damage mechanics assessment of the Larsen B ice shelf prior to collapse: Toward a physically-based calving law, Geophys. Res. Lett., 39, L18502, doi:10.1029/2012GL053317, 2012.

Borstad, C. P., Rignot, E., Mouginot, J., and Schodlok, M. P.: Creep deformation and buttressing capacity of damaged ice shelves: theory and application to Larsen $\mathrm{C}$ ice shelf, The Cryosphere, 7, 1931-1947, doi:10.5194/tc-7-1931-2013, 2013.

Bueler, E. and Brown, J.: Shallow shelf approximation as a "sliding law" in a thermomechanically coupled ice sheet model, J. Geophys. Res., 114, F03008, doi:10.1029/2008JF001179, 2009.

Cazenave, A. and Llovel, W.: Contemporary sea level rise, Annual Review of Marine Science, 2, 145-173, 2010.

Church, J., White, N., Konikow, L., Domingues, C., Cogley, J., Rignot, E., Gregory, J., van den Broeke, M., Monaghan, A., and Velicogna, I.: Revisiting the Earth's sea-level and energy budgets from 1961 to 2008, Geophys. Res. Lett., 38, L18601, doi:10.1029/2011GL048794, 2011.

Cook, A. J. and Vaughan, D. G.: Overview of areal changes of the ice shelves on the Antarctic Peninsula over the past 50 years, The Cryosphere, 4, 77-98, doi:10.5194/tc-4-77-2010, 2010.

Duddu, R. and Waisman, H.: A temperature dependent creep damage model for polycrystalline ice, Mech. Mater., 46, 23-41, doi:10.1016/j.mechmat.2011.11.007, 2012a.

Duddu, R. and Waisman, H.: A nonlocal continuum damage mechanics approach to simulation of creep fracture in ice sheets, Comput. Mech., 51, 961-974, doi:10.1007/s00466-012-0778-7, $2012 b$.

Duddu, R., Bassis, J. N., and Waisman, H.: A numerical investigation of surface crevasse propagation in glaciers using nonlocal continuum damage mechanics: AN INVESTIGATION OF CREVASSE PROPAGATION, Geophys. Res. Lett., 40, 30643068, doi:10.1002/grl.50602, 2013.

Dupont, T. K. and Alley, R. B.: Assessment of the importance of ice-shelf buttressing to ice-sheet flow, Geophys. Res. Lett., 32, L04503, doi:10.1029/2004GL022024, 2005.

Erdogan, F. and Sih, G.: On the crack extension in plates under plane loading and transverse shear, J. Basic Eng., 85, 519-527, 1963.

Fretwell, P., Pritchard, H. D., Vaughan, D. G., Bamber, J. L., Barrand, N. E., Bell, R., Bianchi, C., Bingham, R. G., Blankenship, D. D., Casassa, G., Catania, G., Callens, D., Conway, H., Cook, A. J., Corr, H. F. J., Damaske, D., Damm, V., Ferraccioli, F., Forsberg, R., Fujita, S., Gim, Y., Gogineni, P., Griggs, J. A., Hindmarsh, R. C. A., Holmlund, P., Holt, J. W., Jacobel, R. W., Jenkins, A., Jokat, W., Jordan, T., King, E. C., Kohler, J., Krabill, W., Riger-Kusk, M., Langley, K. A., Leitchenkov, G., Leuschen, C., Luyendyk, B. P., Matsuoka, K., Mouginot, J., Nitsche, F. O., Nogi, Y., Nost, O. A., Popov, S. V., Rignot, E., Rippin, D. M., Rivera, A., Roberts, J., Ross, N., Siegert, M. J., Smith, A. M., Steinhage, D., Studinger, M., Sun, B., Tinto, B. K., Welch, B. C., Wilson, D., Young, D. A., Xiangbin, C., and Zirizzotti, A.: Bedmap2: improved ice bed, surface and thickness datasets for Antarctica, The Cryosphere, 7, 375-393, doi:10.5194/tc-7-3752013, 2013.

Glasser, N. F. and Scambos, T. A.: A structural glaciological analysis of the 2002 Larsen B ice-shelf collapse, J. Glaciol., 54, 3-16, 2008.
Glasser, N. F., Kulessa, B., Luckman, A., Jansen, D., King, E. C., Sammonds, P. R., Scambos, T. A., and Jezek, K. C.: Surface structure and stability of the Larsen $\mathrm{C}$ ice shelf, Antarctic Peninsula, J. Glaciol., 55, 400-410, 2009.

Gregory, J. M., White, N. J., Church, J. A., Bierkens, M. F. P., Box, J. E., van den Broeke, M. R., Cogley, J. G., Fettweis, X., Hanna, E., Huybrechts, P., Konikow, L. F., Leclercq, P. W., Marzeion, B., Oerlemans, J., Tamisiea, M. E., Wada, Y., Wake, L. M., and van de Wal, R. S.: Twentieth-century global-mean sea-level rise: is the whole greater than the sum of the parts?, J. Climate, 26, 4467-4499, doi:10.1175/JCLI-D-12-00319.1, 2012.

Gudmundsson, G. H.: Ice-shelf buttressing and the stability of marine ice sheets, The Cryosphere, 7, 647-655, doi:10.5194/tc-7647-2013, 2013

Habermann, M., Maxwell, D., and Truffer, M.: Reconstruction of basal properties in ice sheets using iterative inverse methods, J. Glaciol., 58, 795-807, doi:10.3189/2012JoG11J168, 2012.

Hanna, E., Navarro, F. J., Pattyn, F., Domingues, C. M., Fettweis, X., Ivins, E. R., Nicholls, R. J., Ritz, C., Smith, B., Tulaczyk, S., Whitehouse, P. L., and Zwally, H. J.: Ice-sheet mass balance and climate change, Nature, 498, 51-59, doi:10.1038/nature12238, 2013.

Hulbe, C. L., LeDoux, C., and Cruikshank, K.: Propagation of long fractures in the Ronne Ice Shelf, Antarctica, investigated using a numerical model of fracture propagation, J. Glaciol., 56, 459472, 2010.

Humbert, A.: Numerical simulations of the ice flow dynamics of Fimbulisen, in: FRISP Report, Vol. 17, 2006.

Humbert, A., Kleiner, T., Mohrholz, C. O., Oelke, C., Greve, R., and Lange, M. A.: A comparative modeling study of the Brunt Ice Shelf/Stancomb-Wills Ice Tongue system, East Antarctica, J. Glaciol., 55, 53-65, 2009.

Jansen, D., Kulessa, B., Sammonds, P. R., Luckman, A., King, E., and Glasser, N. F.: Present stability of the Larsen C ice shelf, Antarctic Peninsula, J. Glaciol., 56, 593-600, 2010.

Jansen, D., Luckman, A., Kulessa, B., Holland, P. R., and King, E. C.: Marine ice formation in a suture zone on the Larsen C Ice Shelf and its influence on ice shelf dynamics: Marine Ice Impact on Ice Shelf Dynamics, J. Geophys. Res.-Earth, 118, 1628-1640, doi:10.1002/jgrf.20120, 2013.

Jezek, K. C., Farness, K., Carande, R., Wu, X., and LabelleHamer, N.: RADARSAT 1 synthetic aperture radar observations of Antarctica: Modified Antarctic Mapping Mission, 2000, Radio Sci., 38, 8067, doi:10.1029/2002RS002643, 2003.

Joughin, I. and Alley, R. B.: Stability of the West Antarctic ice sheet in a warming world, Nat. Geosci., 4, 506-513, doi:10.1038/ngeo1194, 2011.

Khazendar, A., Rignot, E., and Larour, E.: Larsen B Ice Shelf rheology preceding its disintegration inferred by a control method, Geophys. Res. Lett., 34, L19503, doi:10.1029/2007GL030980, 2007.

Le Brocq, A. M., Payne, A. J., and Vieli, A.: An improved Antarctic dataset for high resolution numerical ice sheet models (ALBMAP v1), Earth Syst. Sci. Data, 2, 247-260, doi:10.5194/essd-2-247-2010, 2010.

Levermann, A., Bamber, J. L., Drijfhout, S., Ganopolski, A., Haeberli, W., Harris, N. R. P., Huss, M., Krüger, K., Lenton, T. M., Lindsay, R. W., Notz, D., Wadhams, P., and Weber, S.: Potential 
climatic transitions with profound impact on Europe, Clim. Change, 110, 845-878 doi:10.1007/s10584-011-0126-5, 2011.

Levermann, A., Albrecht, T., Winkelmann, R., Martin, M. A., Haseloff, M., and Joughin, I.: Kinematic first-order calving law implies potential for abrupt ice-shelf retreat, The Cryosphere, 6 , 273-286, doi:10.5194/tc-6-273-2012, 2012.

Levermann, A., Clark, P. U., Marzeion, B., Milne, G. A., Pollard, D., Radic, V., and Robinson, A.: The multimillennial sea-level commitment of global warming, P. Natl. Acad. Sci., doi:10.1073/pnas.1219414110, 2013.

Logan, L., Catania, G., Lavier, L., and Choi, E.: A novel method for predicting fracture in floating ice, J. Glaciol., 59, 750-758, doi:10.3189/2013JoG12J210, 2013.

Luckman, A., Jansen, D., Kulessa, B., King, E. C., Sammonds, P., and Benn, D. I.: Basal crevasses in Larsen C Ice Shelf and implications for their global abundance, The Cryosphere, 6, 113-123, doi:10.5194/tc-6-113-2012, 2012.

Lythe, M. B., Vaughan, D. G., Lythe, M. B., Vaughan, D. G., and the BEDMAP Consortium: BEDMAP: A new ice thickness and subglacial topographic model of Antarctica, J. Geophys. Res., 106, 11335-11351, 2001.

Ma, Y., Gagliardini, O., Ritz, C., Gillet-Chaulet, F., Durand, G., and Montagnat, M.: Enhancement factors for grounded ice and ice shelves inferred from an anisotropic ice-flow model, J. Glaciol., 56, 805-812, doi:10.3189/002214310794457209, 2010.

MacAyeal, D. and Sergienko, O. V.: The flexural dynamics of melting ice shelves, Ann. Glaciol., 54, 1-10, doi:10.3189/2013AoG63A256 2013.

MacAyeal, D. R., Scambos, T. A., Hulbe, C. L., and Fahnestock, M. A.: Catastrophic ice-shelf break-up by an ice-shelf-fragmentcapsize mechanism, J. Glaciol., 49, 22-36, 2003.

McGrath, D., Steffen, K., Rajaram, H., Scambos, T., Abdalati, W., and Rignot, E.: Basal crevasses on the Larsen C Ice Shelf, Antarctica: Implications for meltwater ponding and hydrofracture, Geophys. Res. Lett., 39, L16504, doi:10.1029/2012GL052413, 2012a.

McGrath, D., Steffen, K., Scambos, T., Rajaram, H., Casassa, G., and Lagos, J.: Basal crevasses and associated surface crevassing on the Larsen $\mathrm{C}$ ice shelf, Antarctica, and their role in ice-shelf instability, Ann. Glaciol., 58, 10-18, doi:10.3189/2012AoG60A005, 2012b.

Nye, J. F.: The distribution of stress and velocity in glaciers and ice-sheets, P. Roy. Soc. Lond. A Mat., 239, 113-133, 1957.

Plate, C., Müller, R., Humbert, A., and Gross, D.: Evaluation of the criticality of cracks in ice shelves using finite element simulations, The Cryosphere, 6, 973-984, doi:10.5194/tc-6-973-2012, 2012.

Pralong, A. and Funk, M.: Dynamic damage model of crevasse opening and application to glacier calving, J. Geophys. Res., 110, B01309, doi:10.1029/2004JB003104, 2005.

Press, W. H., Teukolsky, S. A., Vetterling, W. T., and Flannery, B. P.: Numerical recipes in C++: the art of scientific computing, Vol. 994, Cambridge University Press Cambridge, 2009.

Pritchard, H. D., Ligtenberg, S. R. M., Fricker, H. A., Vaughan, D. G., van den Broeke, M. R., and Padman, L.: Antarctic icesheet loss driven by basal melting of ice shelves, Nature, 484, 502-505, doi:10.1038/nature10968, 2012.
Rack, W. and Rott, H.: Pattern of retreat and disintegration of the Larsen B ice shelf, Antarctic Peninsula, Ann. Glaciol., 39, 505510, 2004.

Rignot, E., Casassa, G., Gogineni, P., Krabill, W., Rivera, A., and Thomas, R.: Accelerated ice discharge from the Antarctic Peninsula following the collapse of Larsen B ice shelf, Geophys. Res. Lett, 31, L18401, doi:10.1029/2004GL020697, 2004.

Rignot, E., Mouginot, J., and Scheuchl, B.: Ice Flow of the Antarctic Ice Sheet, Science, 333, 1427-1430, doi:10.1126/science.1208336, 2011a.

Rignot, E., Velicogna, I., van den Broeke, M. R., Monaghan, A., and Lenaerts, J.: Acceleration of the contribution of the Greenland and Antarctic ice sheets to sea level rise, Geophys. Res. Lett., 38, L05503, doi:10.1029/2011GL046583, 2011b.

Rignot, E., Jacobs, S., Mouginot, J., and Scheuchl, B.: Ice Shelf Melting Around Antarctica, Science, 341, 266-270, doi:10.1126/science.1235798, 2013.

Rist, M. A., Sammonds, P. R., Murrell, S. A. F., Meredith, P. G., Doake, C. S. M., Oerter, H., and Matsuki, K.: Experimental and theoretical fracture mechanics applied to Antarctic ice fracture and surface crevassing, J. Geophys. Res., 104, 2973-2987, 1999.

Rist, M. A., Sammonds, P. R., Oerter, H., and Doake, C. S. M.: Fracture of Antarctic shelf ice, J. Geophys. Res., 107, ECV 2-1ECV 2-13, doi:10.1029/2000JB000058, 2002.

Rott, H., Müller, F., Nagler, T., and Floricioiu, D.: The imbalance of glaciers after disintegration of Larsen-B ice shelf, Antarctic Peninsula, The Cryosphere, 5, 125-134, doi:10.5194/tc-5-1252011, 2011.

Saheicha, K., Sandhäger, H., and Lange, M. A.: Modelling the Flow Regime of Filchner-Schelfeis, in: FRISP Report, 14, 5862, 2006

Sandhäger, H.: Numerical study on the influence of fractures and zones of weakness on the flow regime of Larsen Ice Shelf, in: FRISP Report, vol. 14, 2003.

Sandhäger, H., Rack, W., and Jansen, D.: Model investigations of Larsen B Ice Shelf dynamics prior to the breakup, in: FRISP Report, Vol. 16, 5-7, 2005.

Scambos, T. A., Hulbe, C., Fahnestock, M., and Bohlander, J.: The link between climate warming and break-up of ice shelves in the Antarctic Peninsula, J. Glaciol., 46, 516-530, 2000.

Scambos, T. A., Hulbe, C., and Fahnestock, M.: Climate-induced ice shelf disintegration in the Antarctic Peninsula, Antarct. Res. Ser., 79, 79-92, 2003.

Scambos, T. A., Haran, T., Fahnestock, M., Painter, T., and Bohlander, J.: MODIS-based Mosaic of Antarctica (MOA) data sets: Continent-wide surface morphology and snow grain size, Remote Sens. Environ., 111, 242-257, doi:10.1016/j.rse.2006.12.020, 2007.

Scambos, T. A., Fricker, H. A., Liu, C. C., Bohlander, J., Fastook, J., Sargent, A., Massom, R., and Wu, A. M.: Ice shelf disintegration by plate bending and hydro-fracture: Satellite observations and model results of the 2008 Wilkins ice shelf break-ups, Earth Planet. Sc. Lett., 280, 51-60, 2009.

Schulson, E. M. and Duval, P.: Creep and Fracture of Ice, Cambridge University Press, The Edinburgh Building, Cambridge CB2 8RU, UK, 416 pp., 2009.

Shepherd, A., Ivins, E. R., A, G., Barletta, V. R., Bentley, M. J., Bettadpur, S., Briggs, K. H., Bromwich, D. H., Forsberg, R., Galin, N., Horwath, M., Jacobs, S., Joughin, I., King, M. A., Lenaerts, J. 
T. M., Li, J., Ligtenberg, S. R. M., Luckman, A., Luthcke, S. B., McMillan, M., Meister, R., Milne, G., Mouginot, J., Muir, A., Nicolas, J. P., Paden, J., Payne, A. J., Pritchard, H., Rignot, E., Rott, H., Sørensen, L. S., Scambos, T. A., Scheuchl, B., Schrama, E. J. O., Smith, B., Sundal, A. V., Angelen, J. H. v., Berg, W. J. v. d., Broeke, M. R. v. d., Vaughan, D. G., Velicogna, I., Wahr, J., Whitehouse, P. L., Wingham, D. J., Yi, D., Young, D., and Zwally, H. J.: A Reconciled Estimate of Ice-Sheet Mass Balance, Science, 338, 1183-1189, doi:10.1126/science.1228102, 2012.

Shyam Sunder, S. and Wu, M. S.: Crack nucleation due to elastic anisotropy in polycrystalline ice, Cold Reg. Sci. Technol., 18, 29-47, 1990.

Timmermann, R. and Hellmer, H. H.: Southern Ocean warming and increased ice shelf basal melting in the twenty-first and twentysecond centuries based on coupled ice-ocean finite-element modelling, Ocean Dynam., 63, 1011-1026, doi:10.1007/s10236-0130642-0, 2013.

Timmermann, R., Wang, Q., and Hellmer, H.: Ice shelf basal melting in a global finite-element sea ice/ice shelf/ocean model, Ann. Glaciol., 53, 303-314, doi:10.3189/2012AoG60A156, 2012.

Van den Broeke, M. R., Bamber, J., Lenaerts, J., and Rignot, E.: Ice Sheets and Sea Level: Thinking Outside the Box, Surv. Geophys., 32, 495-505, doi:10.1007/s10712-011-9137-z, 2011.

Van der Veen, C. J.: Fracture mechanics approach to penetration of surface crevasses on glaciers, Cold Reg. Sci. Technol., 27, 31-47, $1998 \mathrm{a}$.

Van der Veen, C. J.: Fracture mechanics approach to penetration of bottom crevasses on glaciers, Cold Reg. Sci. Technol., 27, 213223, 1998b.

Van der Veen, C. J.: Fracture propagation as means of rapidly transferring surface meltwater to the base of glaciers, Geophys. Res. Lett., 34, L01501, doi:10.1029/2006GL028385, 2007.
Vaughan, D. G.: Relating the occurrence of crevasses to surface strain rates, J. Glaciol., 39, 255-266, 1993.

Vaughan, D. G., Corr, H. F. J., Bindschadler, R. A., Dutrieux, P., Gudmundsson, G. H., Jenkins, A., Newman, T., Vornberger, P., and Wingham, D. J.: Subglacial melt channels and fracture in the floating part of Pine Island Glacier, Antarctica, J. Geophys. Res., 117, F03012, doi:10.1029/2012JF002360, 2012.

Vieli, A., Payne, A. J., Du, Z., and Shepherd, A.: Numerical modelling and data assimilation of the Larsen B ice shelf, Antarctic Peninsula, Philos. T. R. Soc. A, 364, 1815-1839, doi:10.1098/rsta.2006.1800, 2006.

Vieli, A., Payne, A. J., Shepherd, A., and Du, Z.: Causes of precollapse changes of the Larsen B ice shelf: Numerical modelling and assimilation of satellite observations, Earth Planet. Sc. Lett., 259, 297-306, 2007.

von Mises, R.: Mechanik der festen Körper im plastisch deformablen Zustand, Göttin. Nachr. Math. Phys, 1, 582-592, 1913.

Walker, C. C., Bassis, J. N., Fricker, H. A., and Czerwinski, R. J.: Structural and environmental controls on Antarctic ice shelf rift propagation inferred from satellite monitoring: Antarctic Ice Shelf Rifting, J. Geophys. Res.-Earth, 118, 1-11, doi:10.1002/2013JF002742, 2013.

Weertman, J.: Can a water-filled crevasse reach the bottom surface of a glacier, IASH Publ., 95, 139-145, 1973.

Winkelmann, R., Martin, M. A., Haseloff, M., Albrecht, T., Bueler, E., Khroulev, C., and Levermann, A.: The Potsdam Parallel Ice Sheet Model (PISM-PIK) - Part 1: Model description, The Cryosphere, 5, 715-726, doi:10.5194/tc-5-715-2011, 2011.

Winkelmann, R., Levermann, A., Martin, M. A., and Frieler, K. Increased future ice discharge from Antarctica owing to higher snowfall, Nature, 492, 239-242, doi:10.1038/nature11616, 2012. 